\title{
Recent Advances in Photodynamic Therapy against Fungal Keratitis
}

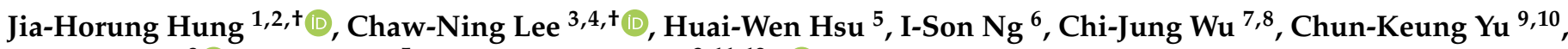 \\ Nan-Yao Lee ${ }^{8} \mathbb{D}$, Yun Chang ${ }^{5}$ and Tak-Wah Wong $3,11,12, * \mathbb{D}$
}

check for

updates

Citation: Hung, J.-H.; Lee, C.-N.; Hsu, H.-W.; Ng, I.-S.; Wu, C.-J.; Yu, C.-K.; Lee, N.-Y.; Chang, Y.; Wong,

T.-W. Recent Advances in

Photodynamic Therapy against Fungal Keratitis. Pharmaceutics 2021, 13, 2011. https://doi.org/10.3390/ pharmaceutics13122011

Academic Editors: Francesca Moret, Greta Varchi and Nejat Duzgunes

Received: 22 September 2021

Accepted: 20 November 2021

Published: 26 November 2021

Publisher's Note: MDPI stays neutral with regard to jurisdictional claims in published maps and institutional affiliations.

Copyright: (c) 2021 by the authors. Licensee MDPI, Basel, Switzerland. This article is an open access article distributed under the terms and conditions of the Creative Commons Attribution (CC BY) license (https:/ / creativecommons.org/licenses/by/ $4.0 /)$.
1 Institute of Clinical Medicine, College of Medicine, National Cheng Kung University, Tainan 701, Taiwan; hungjh@mail.ncku.edu.tw

2 Department of Ophthalmology, National Cheng Kung University Hospital, College of Medicine, National Cheng Kung University, Tainan 704, Taiwan

3 Department of Dermatology, National Cheng Kung University Hospital, College of Medicine, National Cheng Kung University, Tainan 704, Taiwan; Joyce060324@gmail.com

4 Institute of Clinical Pharmacy and Pharmaceutical Sciences, College of Medicine, National Cheng Kung University, Tainan 701, Taiwan

5 School of Medicine, National Cheng Kung University, Tainan 701, Taiwan; haley3006@gmail.com (H.-W.H.); c.phoebe.y@gmail.com (Y.C.)

6 Department of Chemical Engineering, National Cheng Kung University, Tainan 701, Taiwan; yswu@mail.ncku.edu.tw

7 National Institute of Infectious Diseases and Vaccinology, National Health Research Institutes, Tainan 704, Taiwan; wucj@nhri.edu.tw

8 Division of Infectious Diseases, Department of Internal Medicine, National Cheng Kung University Hospital, College of Medicine, National Cheng Kung University, Tainan 704, Taiwan; nanyao@mail.ncku.edu.tw

9 Institute of Basic Medical Sciences, College of Medicine, National Cheng Kung University, Tainan 701, Taiwan; dckyu@ncku.edu.tw

10 Department of Microbiology and Immunology, College of Medicine, National Cheng Kung University, Tainan 701, Taiwan

11 Department of Biochemistry and Molecular Biology, College of Medicine, National Cheng Kung University, Tainan 701, Taiwan

12 Center of Applied Nanomedicine, National Cheng Kung University, Tainan 701, Taiwan

* Correspondence: Dr.kentwwong@gmail.com; Tel.: +886-6-2353535 (ext. 5352)

+ These authors contribute equally to this paper.

Abstract: Fungal keratitis is a serious clinical infection on the cornea caused by fungi and is one of the leading causes of blindness in Asian countries. The treatment options are currently limited to a few antifungal agents. With the increasing incidence of drug-resistant infections, many patients fail to respond to antibiotics. Riboflavin-mediated corneal crosslinking (similar to photodynamic therapy (PDT)) for corneal ectasia was approved in the US in the early 2000s. Current evidence suggests that PDT could have the potential to inhibit fungal biofilm formation and overcome drug resistance by using riboflavin and rose bengal as photosensitizers. However, only a few clinical trials have been initiated in anti-fungal keratitis PDT treatment. Moreover, the removal of the corneal epithelium and repeated application of riboflavin and rose bengal are required to improve drug penetration before and during PDT. Thus, an improvement in trans-corneal drug delivery is mandatory for a successful and efficient treatment. In this article, we review the studies published to date using PDT against fungal keratitis and aim to enhance the understanding and awareness of this research area. The potential of modifying photosensitizers using nanotechnology to improve the efficacy of PDT on fungal keratitis is also briefly reviewed.

Keywords: candida; collagen cross-linking; drug delivery; fungal infection; flavin mononucleotide; keratitis; rose bengal; photodynamic therapy; drug-resistance 


\section{Introduction}

According to the World Health Organization (WHO), around 6 million people globally are affected by cornea-related blindness [1]. Corneal opacity is estimated to be responsible for 1.5-2.0 million new cases of monocular blindness each year [1], with etiologies including infection, trauma, inflammation, degeneration, and nutritional deficiency [1]. Among the etiologies, infectious keratitis (IK) stands at the top with an estimated incidence of 2.5-799 per 100,000 population-year [2]. IK can be caused by pathogens, such as bacteria, fungi, virus, parasites, and polymicrobial infections, which may vary depending on different geographic locations and seasons [3].

Bacterial infections make up $79-100 \%$ of IK, depending on the country and study period [1]. Fungal keratitis, on the other hand, is more prevalent in Asian countries [2,3]. It is a serious corneal fungal infection, commonly caused by Candida, Fusarium, and Aspergillus, that often results in blindness and eye loss, especially in developing countries [4]. The global minimal annual incidence is estimated at 1.05 million cases, with the highest rates in Asia and Africa. Even with the advancement of biotechnology, there are few antifungal agents available, including natamycin, amphotericin B, fluconazole, and voriconazole [1]. The situation is complicated by the rapid emergence of drug-resistant fungal keratitis globally $[5,6]$, to the extent that some patients require a full thickness corneal transplantation (penetrating keratoplasty) [7] as treatment. In their 1991 study, Kirkness et al. suggested early intervention with corneal transplantation regarding the management of advanced microbial keratitis [8]. The overall success rate is around 80-90\% [7,9], however graft failure and the recurrence of infection could occur in an active infected eye after operation [10]. Furthermore, the acquired and innate antifungal drug resistance has drastically increased over the past three decades [2]. Moreover, the clinical response to fungal infection does not always correlate with in vitro drug sensitivity testing [11,12]. Hence, new and novel therapies are crucially required to treat and prevent drug-resistant fungal infections.

Photodynamic therapy (PDT) comprises the activation of a specific photosensitizer (PS) with an absorption peak light wavelength of the PS in the presence of oxygen molecules in the tissue and has been widely used to kill cancer cells for three decades [13]. The application of PDT against microorganisms can be dated back to the 1900s when Rabb showed photodynamic effects after exposing Paramecium caudatum to acridine or eosin dyes and illuminated them with sunlight [14]. Even though antimicrobial PDT (aPDT) has shown great potential in treating drug-resistant infectious diseases in vitro and in animal studies, only a few clinical trials are currently ongoing [14,15]. Yet, aPDT has several advantages: (1) It is a local treatment with extremely rare systemic side effects; (2) The antimicrobial effects are medicated by the generation of singlet oxygen and reactive oxygen species (ROS) during irradiation, which damage multiple organelles in a cell, thus PDT resistance has not yet been reported; (3) It functions well both in targeting against planktonic and in biofilm microorganisms [14,15]; (4) Bacteria survive after PDT reduced resistance to antibiotics [16], and some PSs bind more rapidly and selectively to microbials than human cells [14]. So, the killing of the microbials is highly selective in aPDT.

In the field of ophthalmology, PDT was introduced to treat choroidal neovascularization in the 1990s [17]. Before then, the role of PDT in eliminating ocular infection had been rarely studied. Riboflavin-mediated corneal crosslinking (CXL), which is a form of PDT, utilizes riboflavin eye drops as a PS and activates with ultraviolet-A (UVA) to increase the stiffness of the cornea [18]. After its introduction in 2003 by Theo Seiler [18], the application of CXL was extended to IK [19]. Recently, aPDT that utilizes rose bengal as a PS and activation with green light has shown a $72 \%$ success rate in IK patients [20,21].

In this review, we focus on the advancement of aPDT against fungal keratitis, to spotlight a less studied area and enhance the awareness of this area of translational studies.

\section{Fungal Keratitis}

Fungal keratitis was first described by Leber in 1879. It is a serious corneal infection with poor visual prognosis [1,22-24], causing a significant socioeconomic burden, especially 
in developing countries because it commonly affects young male outdoor agricultural workers [25]. The incidence of fungal keratitis has increased over the past three decades due to the frequent use of topical corticosteroids and antibiotics in IK treatment. The estimated minimum annual incidence is around 1 million worldwide with the highest rates in Asia and Africa, and the loss of around 84,143-115,697 eyes [4]. The proportions of fungal keratitis in IK vary from less than $10 \%$ in temperate regions to more than $45 \%$ in tropical and subtropical regions [4]. The most common pathogens causing fungal keratitis are filamentous fungi (Fusarium, Aspergillus) and yeasts (Candida albicans and other Candida species) [1]. Fungi enter corneal stroma through the epithelial defect or extend from the posterior segment through the descent membrane (fungal endophthalmitis). Another entry pathway is through corneoscleral trabeculae into the corneal channel network, since trauma to the corneal epithelium by a contaminated sharp object is very common in farmers in developing countries. In addition to trauma, risk factors for fungal keratitis include pre-existing ocular disorders, systemic disorders, wearing of contact lenses, topical steroid use, and recent ocular surgery [9].

The treatment of fungal keratitis remains challenging because of the difficulty in early diagnosis, limited choices in anti-fungal agents, the emergence of antifungal drug tolerance and resistance [6], and the formation of biofilm, which will be further elaborated in the following section. The mainstay medical treatment is topical anti-fungal agents, e.g., polyenes (amphotericin B, natamycin), triazoles (fluconazole, voriconazole, posaconazole), echinocandins (caspofungin, micafungin), and pyrimidine analogue (flucytosine) with or without systemic antifungal agents [22,24]. Fusarium keratitis is difficult to treat because the Fusarium spp. are intrinsically resistant to most antifungals, including echinocandins [26,27]. Since the approval of natamycin in the 1960s by the US Food and Drug Administration, no new topical antifungal eye drops have been approved and natamycin is currently considered the most effective medication against Fusarium [24].

Among the available antifungal agents, voriconazole has demonstrated the best ocular penetration and broadest coverage of fungal species in vitro [23]. To overcome the disadvantage of poor corneal penetration of antifungal agents, intrastromal or intracameral drug injections have also been proposed [28]. Even with the advancement of new drugs and a new methodology, $40-60 \%$ of fungal keratitis cases are refractory to medical therapy and require surgical intervention $[9,22]$, including multiple keratectomies or penetrating keratoplasty. For patients receiving therapeutic keratoplasty performed in an active infection stage, the five-year survival rate was only $51 \%$ compared to $90 \%$ in cases with inactive infection [8]. Moreover, long-term use of immunosuppressants can lead to repetitive Candida keratitis, which may require multiple corneal transplantations [29]. Overall, fungal keratitis is associated with poorer visual outcomes and remains a great challenge to ophthalmologists $[22,24,26]$.

\section{Drug Resistance and Biofilm in Fungal Keratitis}

The emergence of drug resistance in fungal infection poses a significant threat to public health globally $[5,6,30]$. Cases of multidrug resistant Fusarium keratitis [12,30-32] or azole-resistant Candida keratitis [33] are rare but can be very challenging once they occur. In cases with multidrug-resistant fungal keratitis, the visual outcome is generally devastating despite intense conventional treatments, even requiring some patients to undergo enucleation to control the infection.

The mechanism of antifungal drug resistance (Figure 1) is different among different classes of drugs $[34,35]$. The polyenes are the oldest class of antifungal drugs and include amphotericin B and nystatin. Polyene drugs target ergosterol, a fungal-specific sterol synthesized in the plasma membrane. The sequestration of ergosterol leads to the increase of membrane permeability, eventually causing cell death. Resistance to polyenes is rarely reported, and mainly related to decreased membrane ergosterol, an alteration of cellular stress response (mutations in ERG3 gene) as reported in Candida [34,36]. In some cases, 
treatment with an azole antifungal, which in turn reduces ergosterol, can confer polyene resistance [36].

\begin{tabular}{|l|l|l|}
\hline \multicolumn{2}{|l|}{ Mechanisms of resistance to antifungal drugs that target the cell membrane } & Target the cell wall \\
\hline A. Polyene & B. Azoles & C. Echinocandin \\
\hline & \multicolumn{2}{|c|}{ Molecular mechanism of drug resistance } \\
\hline $\begin{array}{l}\text { - Loss-of-function mutations in ergosterol } \\
\text { biosynthesis genes confer resistance. } \\
\text {-A reduction in ergosterol content. } \\
\text {-Alteration of cellular stress response, } \\
\text { such as HSP90, modulate resistance } \\
\text { phenotypes. }\end{array}$ & $\begin{array}{l}\text {-Increased drug efflux with target alteration or overexpression. } \\
\text {-Alteration of cellular stress response. } \\
\text {-Mutation in ergosterol biosynethesis pathway. }\end{array}$ & $\begin{array}{l}\text {-Mutations in FKS1, FKS2, which encode } \\
\text { the echinocandin target in } \beta-1,3-g l u c a n \\
\text { synthase, a key enzyme for cell wall } \\
\text { biosynthesis. }\end{array}$ \\
\hline
\end{tabular}

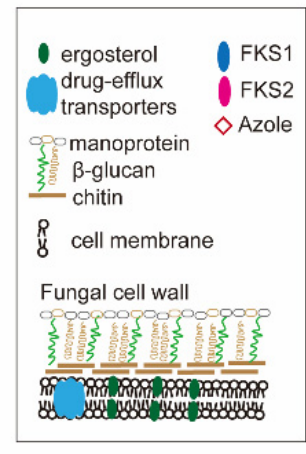

Figure 1. Mechanisms of antifungal agent resistance. Polyenes (A) and azoles (B) are membrane targeting antifungal drugs while echinocandins are cell wall-active agents. (A) Polyene resistance is often attributed to loss-of-function mutations in ergosterol biosynthetic genes which lead to depletion of ergosterol, the fungi-specific cell membrane sterol. Resistance mechanisms for Candida albicans, Cryptococcus neoformans, and Aspergillus fumigatus are outlined in dashes. (B) Azole resistance can result from the upregulation of two classes of efflux pumps that remove the drug from the cell; through the mutation or overexpression of ERG11, which minimizes the impact of the drug on the target; or alterations in ergosterol biosynthesis, such as the loss-of-function mutation of ERG3, which blocks the accumulation of a toxic sterol intermediate that is produced when ERG11 is inhibited. (C) Resistance to echinocandins can result from mutations in FKS1 that minimize the impact of the drug on the target.

Azole antifungal agents are some of the most widely used antifungal agents, and offer activity against many fungal pathogens without the serious nephrotoxic effects observed with amphotericin B [37]. The azoles available in the clinic can be classified into two groups: the triazoles (fluconazole, itraconazole, voriconazole, posaconazole, and isavuconazole) and the imidazoles (ketoconazole). The azole antifungals are also membranetargeted, primarily by inhibiting the cytochrome P450-dependent enzyme lanosterol 14alpha-demethylase, a critical enzyme that converts lanosterol to ergosterol [38]. Triazole resistance is mainly caused by the increased activity of efflux pumps that remove the drug from the cell due to the overexpression or mutations of ERG11 and CYP51 genes, and/or the alteration of cellular stress response genes (loss-of-function of ERG3 gene) [6,35].

Echinocandins constitute the first class of antifungals to target the fungal cell wall. This class of antifungals inhibits $\beta-(1,3)$-D-glucan synthase, a critical enzyme for the synthesis of polysaccharide $\beta-(1,3)$-D-glucan, a component of the cell wall of many fungi. Three semi-synthetic echinocandins, namely caspofungin, micafungin, and anidulafungin, have been developed for clinical use and are usually reserved for invasive fungal keratitis [39]. Clinical experience with this antifungal class suggests that it is among the best tolerated and safest classes of antifungals available [40]. The acquired resistance to echinocandins remains sporadic and varies by region but is possibly increasing, especially among invasive C. glabrata infections with FKS1 and FKS2 mutations [6].

A biofilm is defined as a structured microbial community attached to a surface and encased within a self-produced extracellular matrix [41,42], which blocks the entry of the antifungal agents [43]. Fungi isolated from keratitis are able to produce biofilm [44], impairing the susceptibility of antifungal agents, and protecting the fungi from UV light [44], thus enhancing fungal resistance [6]. The ability of fungi to form biofilms is correlated to their ability to form disease in humans [45], irrespective of the thickness of these biofilms [46]. Only a few antimycotics, such as miconazole (azoles), echinocandins, and liposomal formulations of amphotericin B (polyenes), have shown effectiveness against fungal biofilms [47,48]. Pérez-Laguna et al. reviewed the combination of aPDT and antimicrobial compounds to treat skin and mucosal infections in humans or animals [49]. They concluded that aPDT 
has additive or synergistic effects both in planktonic suspensions and biofilms, which may relate to an increase in membrane permeability by the aPDT in fluconazole-resistant C. albicans strains. Interestingly, combination therapies with natural products may enhance antifungal agents against biofilm. Lactoferricin B, a peptide of bovine lactoferrin exhibiting multiple biological functions, including antimicrobial, antiviral, antioxidant, and immunomodulatory activities, has been proposed to improve biofilm susceptibility to antifungals [50]. Other compounds, including monoterpenes, sesquiterpenes, extracts from microalgae, and Cyanobacteria, also showed enhancement of antifungal agents in fungal biofilm inhibition [51,52]. Their mechanisms are believed to relate to the induction of ROS by antifungal agents and targeting the fungal oxidative defense system [47]. Table 1 summarizes the treatment outcome of IK caused by multidrug-resistant fungi with traditional treatments.

Table 1. Outcomes of case reports affected by multidrug resistant fungal keratitis.

\begin{tabular}{|c|c|c|c|c|c|}
\hline Ref. (Year) Citation & Pathogens & Initial VA & Antifungal Drugs & Surgery & Outcome \\
\hline Sponsel (2002) [30] & F. solani & Not mentioned & $\begin{array}{l}\text { AMB-intravenous, topical } \\
\text { KTC-topical } \\
\text { NAT-topical } \\
\text { POS-PO, topical }\end{array}$ & PK & VA: $6 / 30$ \\
\hline Guarro (2003) [53] & F. polyphialidicum & $1 / 200$ & AMB-topical & $\begin{array}{l}\text { Corneal } \\
\text { transplantation }\end{array}$ & $\begin{array}{l}\text { VA: } 20 / 40 \\
\text { (improved) }\end{array}$ \\
\hline \multirow{3}{*}{$\mathrm{Tu}(2007)$ [54] } & F. solani & $\mathrm{HM}$ & $\begin{array}{l}\text { AMB-IVI, topical } \\
\text { FLC-PO } \\
\text { ITC-PO } \\
\text { NAT-topical } \\
\text { POS-PO } \\
\text { VRC-intravenous, IVI, PO }\end{array}$ & PK for 3 times & VA: CF (improved) \\
\hline & Fusarium sp. & Not mentioned & $\begin{array}{l}\text { AMB-topical } \\
\text { FLC-PO } \\
\text { NAT-topical } \\
\text { VRC-PO, topical } \\
\text { POS-PO, topical }\end{array}$ & PK for 2 times & $\begin{array}{l}\text { Resolution of } \\
\text { inflammation }\end{array}$ \\
\hline & Fusarium sp. & Not mentioned & $\begin{array}{l}\text { AMB-AC injection, topical } \\
\text { CYA-topical } \\
\text { FLC-PO } \\
\text { NAT-topical } \\
\text { POS-PO } \\
\text { VRC-IVI, PO, topical }\end{array}$ & $\begin{array}{l}\text { PK, penetrating } \\
\text { patch graft }\end{array}$ & $\begin{array}{l}\text { Poor vision, awaiting } \\
\text { repeat corneal } \\
\text { transplantation }\end{array}$ \\
\hline $\begin{array}{l}\text { Proença-Pina } \\
\text { (2010) [55] }\end{array}$ & F. solani & $\mathrm{HM}$ & $\begin{array}{l}\text { AMB-AC irrigation, topical } \\
\text { VRC-PO, topical }\end{array}$ & PK & $\begin{array}{l}\text { VA: } 20 / 50 \\
\text { (improved) }\end{array}$ \\
\hline Edelstein (2012) [56] & F. solani & $\mathrm{HM}$ & $\begin{array}{l}\text { AMB-ICI, IVI, topical } \\
\text { FLC-PO } \\
\text { ITC-PO } \\
\text { NAT-topical } \\
\text { POS-PO } \\
\text { VRC-PO, topical }\end{array}$ & $\begin{array}{l}\text { PK for } 2 \text { times, pars } \\
\text { plana vitrectomies, } \\
\text { enucleation }\end{array}$ & Enucleation \\
\hline Antequera (2015) [31] & F. solani & - & $\begin{array}{l}\text { AMB-intravenous } \\
\text { CAS-intravenous } \\
\text { VRC-intravenous, PO, } \\
\text { topical }\end{array}$ & Enucleation & Enucleation \\
\hline Sara (2016) [12] & F. solani & $6 / 12$ & $\begin{array}{l}\text { AMB-IVI } \\
\text { NAT-topical } \\
\text { VRC-IVI, PO, topical }\end{array}$ & PK, enucleation & Enucleation \\
\hline
\end{tabular}

AC: Anterior chamber; AMB: Amphotericin B; CAS: Caspofungin; CF: Counting fingers; CYA: Cyclosporine A; FLC: Fluconazole; HM: Hand movement; ICI: Intracameral injection; ITC: Itraconazole; IVI: Intravitreal injection; KTC: Ketoconazole; NAT: Natamycin; PK: Penetrating keratoplasty; PO: oral; POS: Posaconazole; VA: Visual acuity; VRC: Voriconazole.

\section{The History of Antimicrobial Photodynamic Therapy}

Photodynamic therapy (PDT) has been used as a noninvasive treatment for the selective destruction of pathogenic organisms using a handful of non-toxic PSs since its 
earliest development (Figure 2). After the discovery of penicillin in 1928, the golden era of antibiotics began in the 1940s and lasted until late 1960s with the development of different classes of antibiotics, including aminoglycosides, tetracyclines, chloramphenicols, sulfones, macrolides, glycopeptides, polymyxins, oxazolidinones, ansamycins, quinolones, azoles, and ethambutol [15]. Similarly, the discovery of aPDT has been accelerated by the development of new classes of PSs since the 1900s, nowadays known as the era of drug resistance (Figure 2). The PSs investigated during the era of aPDT renaissance include tetracationic Zn(II) phthalocyanine PS (RLP-068) [57], methylene blue [58], Tin(IV) porphyrins [59], chlorine e6 [60], new formulations of methylene blue [61], riboflavin [62], exeporfinium chloride (XF73) [63], fullerenes [64], indocyanine green [65], 2-((4-pyridinyl)methyl)-1Hphenalen-1-one chloride (SAPYR) [66], curcumin derivative (SACUR-3) [67], hematoporphyrin derivative-Photogem [68], 5-aminolevulinic acid induced protoporphyrin IX (ALA-PpIX) [69], $\mathrm{C}_{28} \mathrm{H}_{42} \mathrm{BrN}_{3} \mathrm{~S}$, phenothiazin-5-ium, 3,7-bis(dibutylamino)-, bromide (PPA904) [70], and curcumin [71].

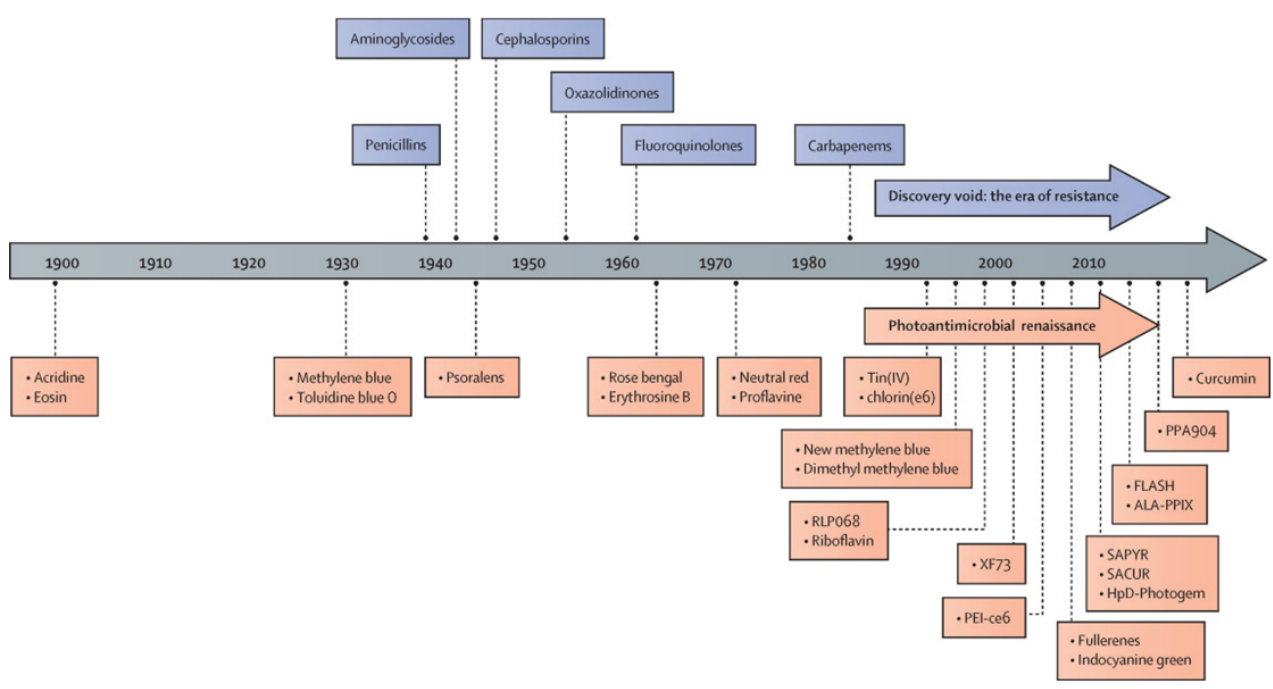

Figure 2. History of antimicrobial photodynamic therapy. RLP068: tetracationic Zn(II) phthalocyanine chloride; XF73: positively charged porphyrin; PEI-ce6: polyethyleneimine chlorin(e6) conjugate; SAPYR: perinapthenone derivative. SACUR: curcumin derivative; HpDPhotogem:haematoporphyrin derivative; FLASH: cationic riboflavin derivative; ALA-PPIX: 5aminolevulinic acid-induced protoporphyrin IX; PPA90: tetrabutyl derivative of methylene blue. Reprinted from ref. [14] in text with permission from the Publisher.

\section{Mechanism of the Photodynamic Action in Fungal Infection}

PS, light, and oxygen in tissue or in a cell are the three key elements of PDT, and none of them is toxic or cell/tissue damaging by itself. Upon excitation by light containing the absorption peaks of a PS (usually red or blue light, near-infrared light and even sunlight [13]), the PS transforms from ground state to the short-lived singlet state, and then relaxed to the triplet state $\left(\mathrm{PS}^{*}\right)$ (Figure 3) [67]. After achieving the triplet state of a PS, two kinds of reaction follow. In the type I reaction, the excited PS reacts through electron transfer with biomolecules, such as lipids, proteins, and amino acids, to yield the superoxide anion radical $\left(\mathrm{O}_{2} \bullet-\right)$ and hydroxyl radical $(\bullet \mathrm{OH}) . \mathrm{O}_{2} \bullet-$ undergoes dismutation to form hydrogen peroxide $\left(\mathrm{H}_{2} \mathrm{O}_{2}\right)$, the precursor of the highly reactive $\bullet \mathrm{OH}$. $\bullet \mathrm{OH}$ is extremely chemically reactive to almost all biological molecules [68]. In the type II reaction, the excited PS yields singlet oxygen $\left({ }^{1} \mathrm{O}_{2}\right)$ through a direct energy transfer to molecular oxygen. Like the hydroxyl radical, ${ }^{1} \mathrm{O}_{2}$ is highly reactive [67]. These two types of reactions compete with each other, and the type II reaction is believed to be the principal mechanism of $\mathrm{O}_{2}$-dependent PDT [69]. In a microorganism, the photodynamic actions should take place where the PS deposited, as the half-life of singlet oxygen and ROS are only within microseconds and the diffusion distance is within micrometers [70]. Therefore, PDT targets 
multiple organelles in a cell. No evidence of any PDT-resistant microorganisms has been reported so far. On the contrary, MRSA was reported to become more sensitive to antibiotics after ICG-mediated PDT, which was partly related to mecA complex gene deletion [16].
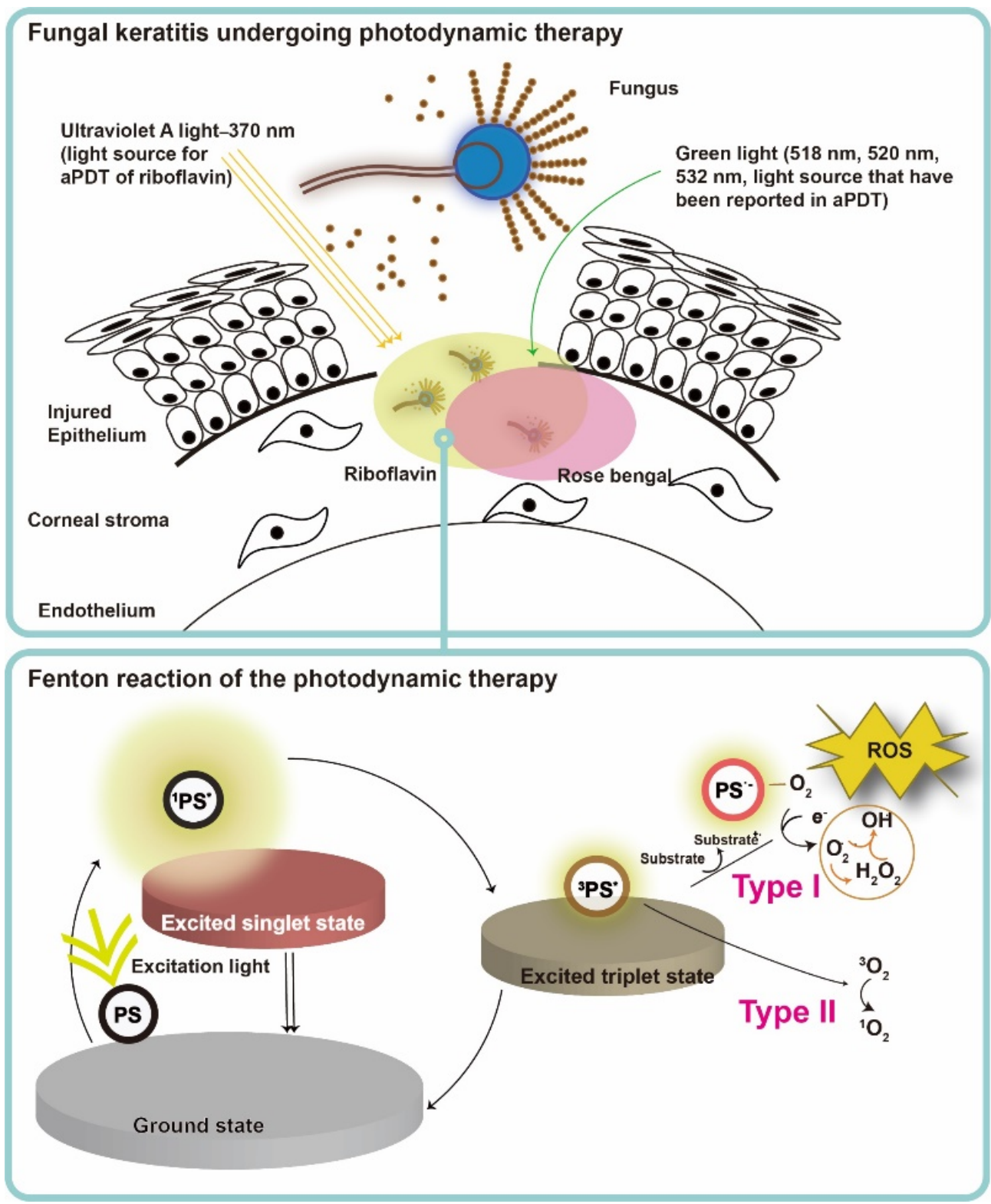

Figure 3. Schematic illustration of antimicrobial photodynamic therapy mechanism for fungal keratitis. The ground-state photosensitizer (PS) absorbs photons and is excited to the first short-lived excited singlet state and either returns to the ground state or undergoes intersystem crossing to a long-lived triplet state. The triplet state PS exerts downstream function via a type I or type II photosensitization process. For type I reaction, charge is transferred from the excited PS to oxygen $\left(\mathrm{O}_{2}\right)$, and therefore leading to the formation of hydrogen peroxide $\left(\mathrm{H}_{2} \mathrm{O}_{2}\right)$, hydroxyl radical (HO.), and superoxide anion $\left(\mathrm{O}_{2-} \cdot\right)$. For type II reaction, the triplet PS undergoes energy exchange with triplet ground state oxygen, leading to the formation of singlet oxygen ${ }^{1} \mathrm{O}_{2}$. Type I and type II reactions can occur at the same time during irradiation. Nevertheless, type II reaction is mainly involved in antimicrobial photodynamic action. The reaction depends most importantly on PS used and the concentration of $\mathrm{O}_{2}$ in aPDT. 


\section{Antimycotic Photodynamic Therapy}

Most published studies of antimycotic PDT today focus on in vitro investigations [72,73]. Table 2 summarizes the clinical applications of aPDT against fungal keratitis. PSs used in aPDT for IK include toluidine blue O (TBO), methylene blue (MB) [74,75], rose bengal (RB) [20], and riboflavin (RBF) [76,77]. The following section focuses on PSs in antimycotic studies.

Table 2. Clinical reports of antimycotic photodynamic therapy for fungal keratitis.

\begin{tabular}{|c|c|c|c|c|c|c|}
\hline Ref. (Year) Citation & Pathogens & Study Type & Case Number & Photosensitizer & $\begin{array}{c}\text { Light Source } \\
\text { (Wavelength), } \\
\text { Irradiance, } \\
\text { Irradiation Time or } \\
\text { Radiant Exposure }\end{array}$ & Outcome \\
\hline \multirow{2}{*}{ Iseli (2008) [19] } & Acremonium sp. & \multirow{2}{*}{ Case reports } & 1 & $0.1 \%$ RFB & $\begin{array}{l}\text { UVA } \\
3.0 \mathrm{~mW} / \mathrm{cm}^{2} \\
30 \mathrm{~min}\end{array}$ & $\begin{array}{l}\text { VA: CF after CXL, } \\
\text { 20/30 after DALK } \\
\text { ( } 8 \text { months after CXL) } \\
\text { (improved) }\end{array}$ \\
\hline & Fusarium sp. & & 1 & $0.1 \%$ RFB & $\begin{array}{l}\text { UVA } \\
3.0 \mathrm{~mW} / \mathrm{cm}^{2} \\
30 \mathrm{~min}\end{array}$ & $\begin{array}{l}\text { Corneal infiltrate } \\
\text { progressed after CXL } \\
\rightarrow \text { PK }\end{array}$ \\
\hline $\begin{array}{l}\text { Uddaraju } \\
\text { (2015) [78] }\end{array}$ & $\begin{array}{l}\text { Aspergillus sp., } \\
\text { Fusarium sp. }\end{array}$ & $\mathrm{RCT}$ & 6 & $0.1 \%$ RFB & $\begin{array}{l}\text { UVA }(370 \mathrm{~nm}) \\
3.0 \mathrm{~mW} / \mathrm{cm}^{2} \\
30 \mathrm{~min}\end{array}$ & $\begin{array}{l}\text { VA: HM ( } 2 \text { out of } \\
6 \text { cases), LP ( } 2 \text { out of } \\
6 \text { cases), } 6 / 60 \text { ( } 2 \text { out of } \\
6 \text { cases) }(\sim 20 \% \text { cases } \\
\text { improved; } \sim 20 \% \text { cases } \\
\text { stable disease, } \\
\sim 60 \% \text { cases worsened })\end{array}$ \\
\hline Vajpayee (2015) [79] & $\begin{array}{l}\text { Aspergillus sp., } \\
\text { Fusarium sp. }\end{array}$ & Retrospective study. & 20 & $0.1 \%$ RFB & $\begin{array}{l}\text { UVA }(365 \mathrm{~nm}) \\
3.0 \mathrm{~mW} / \mathrm{cm}^{2} \\
30 \mathrm{~min}\end{array}$ & $\begin{array}{l}\text { BCVA: } 1.13 \pm 0.55 \\
\text { (stable disease) }\end{array}$ \\
\hline $\begin{array}{l}\text { Kasetsuwan } \\
\text { (2016) [80] }\end{array}$ & $\begin{array}{l}\text { Fusarium sp., } \\
\text { Aspergillus sp., } \\
\text { Purpureocillium sp., } \\
\text { Pythium sp. }\end{array}$ & RCT & 8 & $0.1 \%$ RFB & $\begin{array}{l}\text { UVA }(365 \mathrm{~nm}) \\
3.0 \mathrm{~mW} / \mathrm{cm}^{2} \\
30 \mathrm{~min}\end{array}$ & $\begin{array}{l}\text { Median size of } \\
\text { stromal infiltration: } \\
30.2 \mathrm{~mm}^{2} \rightarrow 9.1 \mathrm{~mm}^{2} \\
\text { Median size of } \\
\text { epithelial defect: } \\
23.7 \mathrm{~mm}^{2} \rightarrow 1.42 \mathrm{~mm}^{2}\end{array}$ \\
\hline Amescua (2017) [81] & Fusarium sp. & Case reports & 1 & $0.1 \% \mathrm{RB}$ & $\begin{array}{l}\text { Green light LED } \\
(518 \mathrm{~nm}) \\
0.9 \mathrm{~J} / \mathrm{cm}^{2} \rightarrow 1.8 \mathrm{~J} / \mathrm{cm}^{2}\end{array}$ & $\begin{array}{l}\text { Clear cornea with fine } \\
\text { endothelial function }\end{array}$ \\
\hline $\begin{array}{l}\text { Mikropoulos } \\
\text { (2019) [82] }\end{array}$ & P. lilacinum & Case report & 1 & RFB & $\begin{array}{l}\text { UVA } \\
9.0 \mathrm{~mW} / \mathrm{cm}^{2} \\
30 \mathrm{~min} \\
\text { (intraoperative) }\end{array}$ & $\begin{array}{l}\text { VA: CF at } 1 \mathrm{~m} \text { (stable } \\
\text { disease) }\end{array}$ \\
\hline \multirow[t]{2}{*}{ Naranjo (2019) [20] } & Fusarium sp. & \multirow{2}{*}{$\begin{array}{l}\text { Consecutive case } \\
\text { series. }\end{array}$} & 4 & $0.1 \% \mathrm{RB}$ & $\begin{array}{l}\text { Green light LED } \\
6.0 \mathrm{~mW} / \mathrm{cm}^{2} \\
15 \mathrm{~min}\end{array}$ & $\begin{array}{l}\text { BCVA: } 20 / 100,20 / 800 \text {, } \\
\text { HM, NLP (50\% cases } \\
\text { improved; } 25 \% \text { cases } \\
\text { stable disease, } 25 \% \\
\text { cases worsened) }\end{array}$ \\
\hline & Curvularia sp. & & 1 & $0.2 \% \mathrm{RB}$ & $\begin{array}{l}\text { Green light LED } \\
6.0 \mathrm{~mW} / \mathrm{cm}^{2} \\
15 \mathrm{~min}\end{array}$ & $\begin{array}{l}\text { BCVA: } 20 / 50 \\
\text { (improved) }\end{array}$ \\
\hline Prajna (2020) [83] & $\begin{array}{l}\text { Aspergillus sp., } \\
\text { Bipolaris sp., } \\
\text { Colletotrichum sp., } \\
\text { Curvularias sp., } \\
\text { Exserohilum sp., } \\
\text { Fusarium sp., } \\
\text { Scedosporium sp. }\end{array}$ & $\mathrm{RCT}$ & 55 & $0.1 \% \mathrm{RB}$ & $\begin{array}{l}\text { UVA }(365 \mathrm{~nm}) \\
3.0 \mathrm{~mW} / \mathrm{cm}^{2} \\
30 \mathrm{~min}\end{array}$ & $\begin{array}{l}\text { VA: } 3.2 \text { Snellen lines } \\
\text { worse at } 3 \text { months } \\
\text { than baseline VA } \\
\text { (worsened in all cases) }\end{array}$ \\
\hline
\end{tabular}

BCVA: Best-corrected visual acuity; CF: Counting fingers; CXL: Corneal crosslinking; DALK: Deep anterior lamellar keratoplasty; HM: Hand movement; LED: Light emitting diodes; LP: Light perception; NLP: No light perception; PK: Penetrating keratoplasty; RB: rose bengal; RCT: Randomized controlled trial; RFB: riboflavin; UVA: Ultraviolet A; VA: Visual acuity.

\subsection{First-Generation Photosensitizers Porphyrins}

The modern era of PDT began in 1978 after Dougherty et al. purified hematoporphyrin derivatives and produced Photofrin, the first clinically approved PS for the treatment of human cancer [13]. The photodynamic action of hematoporphyrin was discovered on yeast cells as early as 1981 [84]. The uptake of porphyrins by Candida is influenced by 
culture conditions, and the damage caused by porphyrin-mediated PDT is determined by the metabolic activities after irradiation [84]. Most of the porphyrin PSs are highly hydrophobic. Carre et al. investigated a series of natural meso-arylglycosylporphyrins with an amphiphilic character to improve cell permeation and found that antifungal activity is correlated to PS permeation into cells [85]. A recent study showed that TMPyP [5,10,15,20tetrakis(1-methylpyridinium-4-yl)-porphyrin tetra p-toluenesulfonate], a water-soluble porphyrin, accumulates in C. albicans cell wall before irradiation, which makes it unlikely to emerge resistance upon aPDT [86]. One of the beneficial effects of aPDT is that it targets multiple organelles in a cel. Thus, no mutagenic effect occurs on a yeast cell [87]. The effects of aPDT are reduced by human blood plasma and human serum albumin, with its mechanisms explained by the binding of porphyrins to albumin, and the quenching and scavenging of ROS by albumin. The clinical application of porphyrins is currently mainly replaced by the second-generation PSs with higher purity and better tissue selectivity.

\subsection{Second-Generation Photosensitizers}

In view of first-generation PSs which lack specificity to target cancer cells, the secondgeneration PSs are more effective and technically superior to first generation PSs. They are improved in purity, have a longer wavelength absorption, as well as higher photosensitivity and tissue selectivity. Many second-generation PSs are based on porphyrin and chlorin structures [88].

\subsubsection{Phenothiaziniums}

The phenothiaziniums, such as toluidine blue $\mathrm{O}(\mathrm{TBO})$ and methylene blue (MB), can localize in the plasma membrane of yeast cells. Photodynamic action damages the plasma membrane, increasing the permeability of the membrane, thus leading to cell death [89]. De Souza et al. examined the effects of $0.1 \mathrm{mg} / \mathrm{mL}$ MB-mediated aPDT on four different species of Candia genus. After exposing planktonic C. albicans, C dubliniensis, C. krusei, and C. tropicalis to a low power $685 \mathrm{~nm}$ diode laser with $28 \mathrm{~J} / \mathrm{cm}^{2}$, respectively, cell growth in all species was significantly inhibited by MB-PDT compared to the control groups [90]. However, the number and mass of the cells can both influence the effects of aPDT [91]. Giroldo et al. proved that a lower $\mathrm{MB}$ concentration $(0.05 \mathrm{mg} / \mathrm{mL})$ may also effectively inhibit Candida growth with the same light dosage [92]. In a study comparing the aPDT effects among $M B$ with red LED, rose bangal with green LED, and ribloflavin (RBF) with UVA irradiation on inhibited growth of $C$. albicans biofilm, MB with red LED was the most effective treatment to inhibit growth on both staphylococcal and candidal biofilms [93].

TBO is an acidophilic metachromatic dye that has a high affinity for DNA and RNA contents (1). It has been widely used as a vital stain for mucosal lesions and in pathology because of its metachromatic property [94]. The study of TBO in aPDT on C. albicans dates back to 1994 when Wilson et al. showed that $C$. albicans was susceptible to the $\mathrm{TBO} / \mathrm{MB}$ photodynamic approach [95]. A recent comprehensive systemic review was done by Wiench et al. where the authors analyzed 21 studies screened from 393 studies from 1997-2020 in the English literature. In comparison to other PSs (MB, malachite green, $\mathrm{RB}$, riboflavin/blue light $460 \mathrm{~nm}$, new MB N, curcumin, erythrosine and chlorin (e6)), the TBO-PDT effects on C albicans are about in the middle [96]. It was concluded that TBO-PDT clearly exhibits antifungal effects against oral Candida spp., but more investigations are needed to confirm its clinical efficacy.

\subsubsection{5-Aminolevulinic Acid}

Although not a PS itself, aminolevulinic acid (ALA) synthesizes the real photoactivable PPIX in a yeast cell [97]. Among different metabolites of ALA, metalloporphyrin and PPIX are predominantly accumulated in yeast cells and become photosensitive to visible light [98]. Monfrecola et al. evinced the growth inhibition of $C$. albicans after incubation with ALA at a concentration higher than $300 \mathrm{mg} / \mathrm{mL}$ for $3 \mathrm{~h}$ and irradiation $\left(40 \mathrm{~J} / \mathrm{cm}^{2}\right)$ with polychromatic visible light from a slide projector equipped with a $150 \mathrm{~W}$ tungsten 
lamp. Plasma membrane damage was visualized under an electron microscope [99]. In addition to the pathogen damage, ALA-mediated PDT also inhibits virulence factors and reduces in vivo pathogenicity [100]. The treatment can also prolong survival in fungusinfected (Fonsecaea monophora) Galleria mellonella larvae by positively regulating its humoral immunity against infection [101].

ALA-PDT can also inhibit $C$. albicans biofilm in vitro after incubating the fungi in $15 \mathrm{mM}$ ALA for $5 \mathrm{~h}$ followed by exposure to $300 \mathrm{~J} / \mathrm{cm}^{2}$ red light [102]. However, skin damage can occur if the protocol for skin neoplastic lesions $\left(75 \mathrm{~J} / \mathrm{cm}^{2}\right.$ irradiation after $20 \%$ ALA occluded for $4 \mathrm{~h}$ ) is used to treat interdigital mycosis of the feet [72]. Nevertheless, with the advancing knowledge in aPDT, promising results of ALA-PDT for human fungal infections on superficial dermatophytosis and onychomycosis, deep fungal infections have been reported since the 2000s [73]. No English language reports of treating fungal keratitis with ALA-PDT have been recorded so far.

\subsubsection{Phthalocyanines}

Phthalocyanines are the most important colorants developed in the 20th century [103]. They are analogs of two natural porphyrins, hemoglobin and chlorophyll. Phthalocyanine was discovered in 1907, and alongside its copper salts became commercially available in the 1930s as a blue color chromogen. The compound phthalocyanine is just as large as porphyrins. The parental compound has little use in PDT, yet its derivative metal complexes make viable PSs. In the study of testing sulfonated aluminum phthalocyanines $\left(\mathrm{AlPcS}_{n}\right)$ in the context of photochemotherapy, $\mathrm{AlPcS}_{2}$ is found to have the highest photosensitivity compared to $\mathrm{AlPcS}_{1}, \mathrm{AlPcS}_{3}$, and $\mathrm{AlPcS}_{4}$ [104]. Among the phthalocyanine derivatives, zinc(II)-phthalocyanine ( $\mathrm{Zn}(\mathrm{II}) \mathrm{Pc}$ ) has the highest uptake in C. albicans. In comparison to the lipophilic ZnPc, the water-soluble sulphonated derivative $\mathrm{ZnPcS}$ binds more tightly on plasma membranes in both Streptococcus faecium and C. albicans, and causes cell membrane damage after photoactivation [105]. Phthalocyanine derivatives $\mathrm{Zn}(\mathrm{II}) \mathrm{Pc}, \mathrm{ZnPc}$, and ZnPc$\mathrm{TiO} 2$ exhibit fungicidal effects on C. albicans after irradiation with a white light-emitting diode (LED) light source $90 \mathrm{~J} / \mathrm{cm}^{2}$ [106]. A number of phthalocyanine-based PSs have been though different phases of clinical trials for cancer [107], yet on the other hand, clinical trials of phthalocyanine-based aPDT treatment for IK have not been addressed.

\subsubsection{Riboflavin}

Corneal cross-linking (CXL) with RBF and UVA irradiation has become a clinical treatment for corneal ectasia [108]. These ectatic changes have typically been marked by corneal thinning and an increase in the anterior and/or posterior curvatures of the cornea, often leading to high levels of myopia and astigmatism. The most common form of ectasia is keratoconus, and other forms of ectasia can be seen after laser vision correction such as LASIK [109].

As a PS, RBF generates reactive oxygen species when activated by UVA (wavelength $370 \mathrm{~nm}$ ) to form collagen cross-links artificially (Figure 4), mainly via a type II reaction (generation of singlet oxygen) [110]. CXL was described first in the late 1990s in animal studies [111], and in 2003 Wollensak reported the first human study on CXL for keratoconus [18]. It has been approved to treat keratoconus and corneal ectasia post refractive surgery in Europe since January 2007, and in the United States since 2016 [108].

CXL is a process similar to PDT and had been used to treat IK in 2013 [112,113], with bacterial and/or fungal infections (Table 2). There are at least three potential mechanisms by which CXL may benefit patients with infectious corneal ulcers: antimicrobial, anti-inflammatory effects, and increased resistance of corneal tissue to enzymatic degradation [83]. With the increasing interest in CXL to treat IK, PACK-CXL (photoactivated chromophore for infectious keratitis), a new term was coined at the 9th CXL congress in Dublin [114]. 

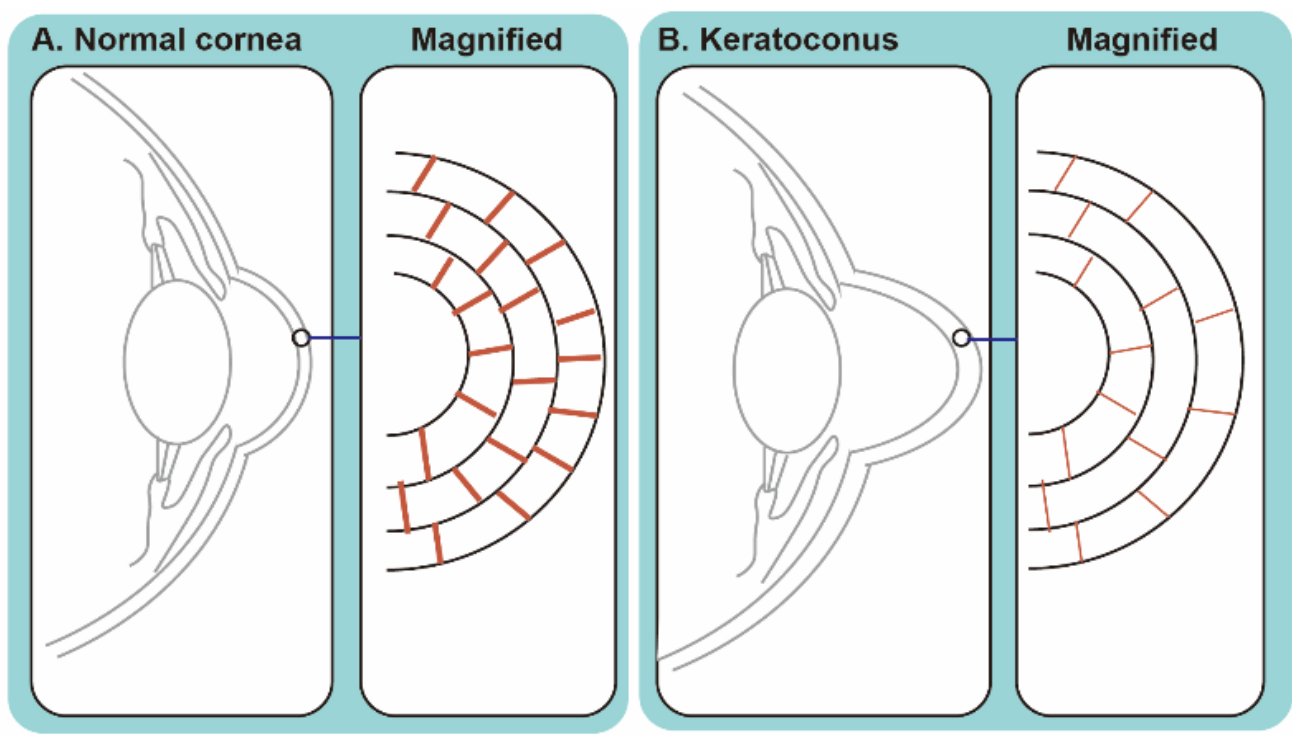

\section{Keratoconus undergoing corneal cross-linking}

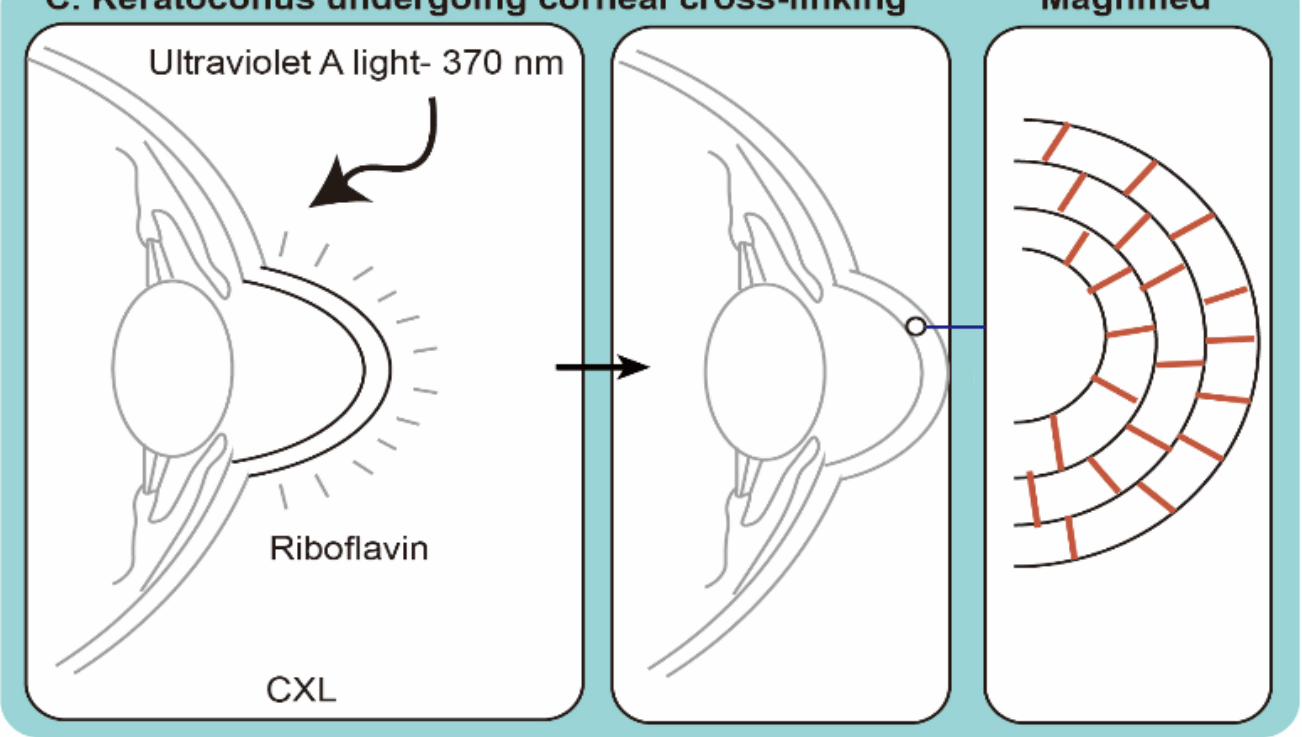

Figure 4. Schematic drawing of corneal crosslinking (CXL) using riboflavin as a photosensitizer and activated with UVA. (A) A normal corneal contour. The magnified view of the corneal stroma showed normal amount of the corneal cross-links. (B) Keratoconus represents a corneal disorder where central or paracentral cornea undergoes progressive thinning and steepening. Magnified view of the corneal stroma showed less cross-link bonds within the extracellular matrix of the stromal collagen (red bars). (C) Upon exposure of riboflavin to UV-A light, the number of covalent bonds between collagen molecules, and between collagen molecules and proteoglycans increased leading to the stiffening of the cornea. The PDT effects is mediated primarily through the generation of singlet oxygen.

The in vitro antimicrobial properties of PACK-CXL against common bacterial and fungal pathogens were studied in 2008 [115]. Since 2014, PACK-CXL has been applied clinically to treat severe IK, either as first-line therapy or an adjuvant therapy in a prospective clinical trial $[19,107,111,112]$. In a study involving 40 IK patients, the addition of PACK-CXL with continued antibiotic treatments resulted in the resolution of infections in $85 \%$ of the cases [116]. The encouraging results of another study involved 16 patients, in which PACK-CXL was used as a primary treatment for bacterial keratitis [117]. However, a 
recent study group found that there is no additional benefit when using PACK-CXL as an adjuvant therapy against bacterial keratitis [118].

Table 2 summarizes the clinical studies of PACK-CXL against fungal infection. Two randomized clinical trials have evaluated the efficacy of adjuvant PACK-CXL in fungal keratitis. In one trial, patients with bacterial and fungal keratitis and Acanthamoeba infestations were randomized to be treated by PACK-CXL versus medical therapy [119]. Although this trial did not identify any benefits of PACK-CXL, these results were difficult to interpret given the inclusion of different types of keratitis of a small sample size. Another small, randomized clinical trial investigated PACK-CXL as an adjuvant therapy for advanced, deep filamentous fungal ulcers and found an increased rate of perforation among those receiving PACK-CXL [78]. Later on, one retrospective series published in 2015 found no benefit to adjuvant PACK-CXL in moderate mycotic keratitis [79]. In the following year, a randomized control trial [80] evaluated the efficacy of PACK-CXL as an adjunctive therapy to treat moderate to severe IK. The results suggested that standard treatment combined with PACK-CXL does not provide additional advantageous effects, regarding the size of stromal infiltrates and corneal epithelial defect in moderate to severe IK over a 30-day period. Furthermore, a recent study evaluated the additional benefits of using PACK-CXL $\left(0.1 \% \mathrm{RBF}, 5.4 \mathrm{~J} / \mathrm{cm}^{2}\right)$ as an adjuvant therapy against fungal keratitis. This randomized controlled clinical trial consisted of four treatment arms: (1) topical natamycin $5 \%$ alone, (2) topical natamycin 5\% plus PACK-CXL, (3) topical amphotericin B $0.15 \%$ alone, and (4) topical amphotericin $0.15 \%$ plus PACK-CXL. The results proved that there was no difference in infiltrate or scar size, percentage of epithelialized or adverse events in PACK-CXL plus antibiotic treatments [83].

In brief, PACK-CXL alone against fungal keratitis appears to be ineffective but might have additional benefits when combined with other treatments. Notably, a recent case report successfully eliminated the infection of post-penetrating keratoplasty multidrugresistant Purpureocillium lilacinum (Paecilomyces sp.) keratitis by using intraoperative PACKCXL during penetrating keratoplasty [82].

\subsubsection{Rose Bengal}

Rose bengal (RB) is a halide derivative of fluorescein [120]. As a well-characterized dye for ophthalmic purposes, RB has long been used to enhance the visualization of corneal lesions by staining dead and devitalised cells, including mucous strands on ocular surfaces [121]. RB-mediated aPDT is able to kill S. aureus, E. coli, and C. albicans with roughly comparable efficiency to that of TBO [91].

In 1993, RB was demonstrated to inhibit $99 \%$ of C. albicans growth with photodynamic effects when combined with glutathione [122]. Another exploratory approach of using $0.1 \%$ $\mathrm{RB}$ as a PS with green light exposure $\left(518 \mathrm{~nm}, 5.4 \mathrm{~J} / \mathrm{cm}^{2}\right)$ also demonstrated efficacy against multidrug-resistant F. keratoplasticum species [81]. Notably, in contrast to the poor visual outcome of conventional treatments against multidrug-resistant fungal keratitis [12,31], this treatment leads to a favorable result (Table 2) [81].

Furthermore, RB-mediated PDT with blue LED $(455 \pm 20 \mathrm{~nm})$ irradiation is effective to inhibit cell growth of C. albicans in planktonic cultures and in biofilms [123]. Similar to PACK-CXL, it can increase resistance of corneal tissue to enzymatic degradation [124]. Interestingly, Wertheimer et al. [125] showed that corneal CXL with RB and green light is largely an oxygen dependent process compared to PACK-CXL [126]. Using enucleated deepithelialized rabbit corneas, the crosslinking procedure with $0.1 \% \mathrm{RB}$ and green light (532 nm, $0.25 \mathrm{~W} / \mathrm{cm}^{2}, 200 \mathrm{~J} / \mathrm{cm}^{2}$ ) produced comparable effects to PACK-CXL [127].

In a study comparing RB-mediated aPDT using green LED $(518 \mathrm{~nm})$ to PACK-CXL using an ultraviolet-A LED array (peak wavelength: $375 \mathrm{~nm}$ ) to treat clinical fungal isolates (F. solani, A. fumigatus, C. albicans) in vitro, only RB-PDT successfully inhibited the growth of all types of fungi. The authors concluded that RB may be a promising PS compared to RBF in aPDT for fungal infection [77]. Recently, clinical applications of RB-PDT for fungal keratitis (Table 2) showed encouraging results. After RB-mediated aPDT, the anterior 
stromal changes with a demarcation line in a human cornea was detected with a slit lamp and anterior segment optical coherence tomography (AS-OCT). Histology showed anterior stromal scarring with disorganization of the collagen bundles at a depth of $220 \mu \mathrm{m}$, which suggested an efficient penetration of RB [128]. RB-mediated PDT is well tolerated in most patients.

Since its first successful case in 2017 introduced by Amescua et al. [81], RB has become a potentially effective PS to treat fungal keratitis. A case series evaluating 18 patients in 2019 confirmed the treatment effect of RB-mediated aPDT against progressive corneal infection (Acanthamoeba, Fusarium spp., Pseudomonas, Curvularia spp.) [20].

An ideal PS for a successful aPDT on fungal keratitis has a high yield of singlet oxygen after irradiation. Peterson et al. developed a singlet oxygen dosimeter detection system that can detect singlet oxygen during experimental RB-PDT using an ex vivo human eye [129]. The dosimeter will clearly help optimize future RB-PDT treatment parameters.

\section{7. aPDT against Fungal Biofilm}

It has been demonstrated that many fungal biofilms are susceptible to aPDT, particularly Candida in dental diseases [130]. An earlier study investigated the effects of Photofrin-mediated PDT (Hg arc lamp, 400-700 nm, $15 \mathrm{~mW} / \mathrm{cm}^{2}, 18 \mathrm{~J} / \mathrm{cm}^{2}$ ) against $C$. albicans biofilms and germ tubes [131]. After exposing biofilm to PDT at $18 \mathrm{~J} / \mathrm{cm}^{2}$, a significant reduction of metabolic activity was demonstrated compared to the biofilm treated with amphotericin B $(10 \mu \mathrm{g} / \mathrm{mL})$ alone. The same group also obtained similar results against biofilms of $C$. albicans and $C$. dubliniensis using erythrosine $(400 \mathrm{mM})$ with green LED light $\left(532 \pm 10 \mathrm{~nm}, 90 \mathrm{~mW} / \mathrm{cm}^{2}, 16.2 \mathrm{~J} / \mathrm{cm}^{2} ; 237 \mathrm{~mW} / \mathrm{cm}^{2}, 42.63 \mathrm{~J} / \mathrm{cm}^{2}\right)$ with significant reductions in CFU/mL of $0.74 \mathrm{log}$ and $0.21 \mathrm{log}$, respectively [131]. Similar to other PS-based aPDT, RB is less effective to treat biofilm if the light dose is low. RB $(12.5 \mu \mathrm{M})$ with green light-emitting diode (LED) $(532 \mathrm{~nm})$ irradiation $\left(16.2 \mathrm{~J} / \mathrm{cm}^{2}\right)$ fails to inhibit heterotypic biofilm formation of C. albicans and B. atrophaeus [132]. Nevertheless, the non-toxic and minimally invasive nature of aPDT supports it to be a potential strategy to control microbial biofilms in the future [133].

\section{Challenges in Trans-Corneal Drug Delivery}

The corneal epithelium together with the tear film provides an effective outermost barrier to prevent pathogens and environmental toxic substances like drugs from entering the eye [134,135]. The barriers for trans-corneal drug delivery are: (1) the limited volume of the eye drop that can be applied to the eye due to the limited precorneal surface area, and most of the volume applied being eliminated during blink reflex triggered by the eye drop; (2) the drugs that remained on the precorneal surface are further degraded by enzymes in the tear film, the outermost layer of the cornea (numbers 9-11 in Figure 5). The thin fluid tear film is composed of three layers: an outer oily layer, an intermediate aqueous layer, and an inner mucin layer (Figure 5). Hydrophilic and hydrophobic drugs are hindered by the two outermost layers, respectively. The drug molecules can be attracted or repulsed by the negatively charged mucins. (3) The fast turnover rate of the tear film $(0.5-2.2 \mu \mathrm{L} / \mathrm{min})$ is accompanied by an estimation that all active ingredients are eliminated on the corneal surface 15-25 min after application [136].

Even though the drug penetrates the tear film, it is estimated that less than $5 \%$ of drug can reach to the anterior chamber because the cornea, scleral, and conjunctival tissue are also effective barriers. The cornea includes three major layers: the epithelium, the stroma, and the endothelium. The hydrophobic corneal epithelium is composed of nonkeratinized stratified squamous cells with intercellular tight junctions, which form a strong permeation barrier for hydrophilic drugs. The epithelium also contains drug efflux pumps and drug-degrading enzymes that prevent drugs from entering. The stroma contains $80 \%$ water and this limits the penetration of hydrophobic drugs. The endothelium also contains tight junctions between cells which hinder hydrophilic drugs, but to a lesser extent in comparison to the epithelium due to its lesser cell thickness. 


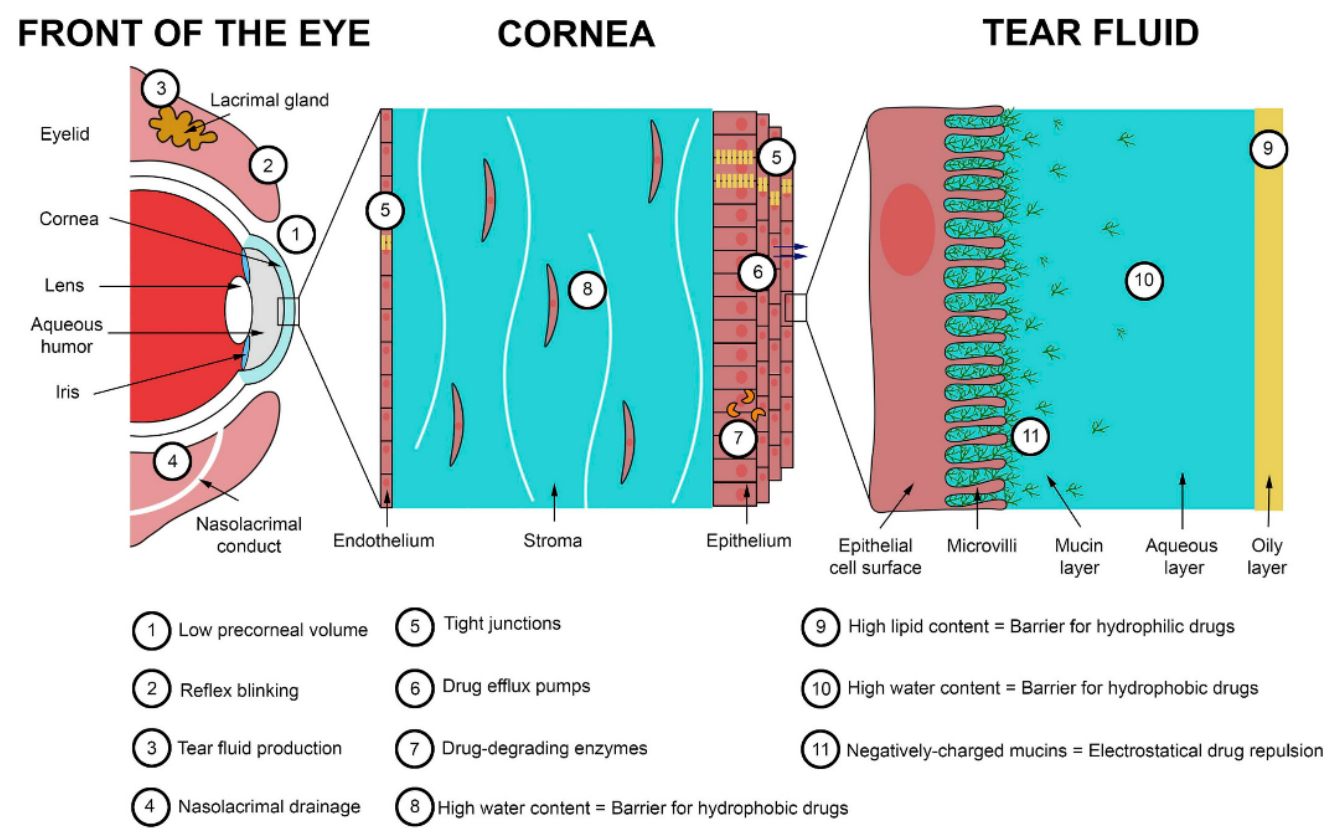

Figure 5. Main static and dynamic barriers for trans-corneal drug delivery [136]. Reprinted from Journal of Controlled Release, Volume 321, doi.org/10.1016/j.jconrel.2020.01.057. Clotilde Jumelle, Shima Gholizadeh, Nasim Annabi, Reza Dana. Advances and limitations of drug delivery systems formulated as eye drops. Reprinted with permission from ref. [136]. Copyright 2021 Elsevier.

At present, PDT is limited to treating superficial infections due to the limitation of visible light penetration and selectivity of PSs to infected tissues. Due to the poor penetration of PSs, the traditional Dresden protocol for IK treatment is comprised of the removal of the central epithelium before the repetition of RBF eye drop instillation every 3-5 min for $30 \mathrm{~min}$, and a continued application during the UV irradiation at $365 \mathrm{~nm}$ and $3 \mathrm{~mW} / \mathrm{cm}^{2}$ for $30 \mathrm{~min}$ [18]. The reason behind repetitive application is to achieve an adequate concentration of RBF or RB in corneal stroma [137]. Nevertheless, all of the current protocols are time-consuming. Postoperative pain and poor corneal healing are also common disadvantages of this procedure. The protocol has been modified into transepithelial (epi-on) and accelerated CXL with a higher-powered light source and a shorter treatment time. Wollensak et al. found that drug penetration in epithelium-on protocol was less successful in comparison to epithelium-off protocols, and its effectiveness requires further studies to confirm [124]. Moreover, a randomized controlled trial found that around one-fifth of epithelium-on PACL-CXL cases resulted in the progression of keratoconus versus none in the epithelial-off cases at one-year follow-up [125].

The consensus in the ophthalmology community is to use an overall fluence of $5.4 \mathrm{~J} / \mathrm{cm}^{2}$ in PACK-CXL, however the standard Dresden protocol remains the mainstream. A slow irradiation may allow improved oxygenation during PDT. Another concern is the depth of drug penetration. Using enucleated and de-epithelialized rabbit eyes, the depth of penetration of RBF or RB was less than $200 \mu \mathrm{m}$ [124]. Deeper drug penetration can be achieved using the ultrasound energy [138] and iontophoresis [139]. Wu et al. found iontophoresis to be a safe and effective method to improve PACK-CXL in an epi-on protocol to treat keratoconus when 21 eyes of 12 patients improved in terms of keratoconus, visual acuity, corneal tomography, and morphological alteration in the corneal stroma at 24 months after the procedure [140].

\section{The Future of aPDT in the Era of Nanomedicine}

The future research direction of aPDT includes exploring PSs other than RBF and RB for fungal keratitis. Different strategies have been applied to improve ocular drug delivery, including the use of penetrating-enhancing compounds (cyclodextrins, chelat- 
ing agents, crown ethers, bile acids and bile salts, cell-penetrating peptides, and other amphiphilic compounds) [135], microemulsions [141], and the incorporation into nanoparticles $[142,143]$. The incorporation of nanotechnology to facilitate the delivery, efficiency, and visualization of PSs in aPDT [130,144,145] may advance the treatment profoundly. With the aid of nanotechnology, a PS can be modified for slow release and at the surface for target delivery, to increase in situ oxygen, elongate absorption peak to treat deeper tissue, and to simultaneously diagnose disease and provide treatment (theranostics). For example, Zhang's team [144] used upconversion nanoparticles encapsulating two PSs (MC540 and ZnPc) in PDT to treat melanoma cells effectively in vitro and in vivo. After irradiation with a near-infrared (NIR) 980-nm laser matrix, the nanoparticles were able to efficiently upconvert the energy to green $(\sim 540 \mathrm{~nm})$ and red $(\sim 660 \mathrm{~nm})$ visible light wavelengths and transfer it to the encapsulated PSs. Recently, Tezuka et al. designed a biodegradable nanoparticle that encapsulates a hydrophobized rose bengal (RB) derivative for NIR-induced upconversion PDT [145]. The nanoparticles exhibited high singlet oxygen yield and high selectivity to cancer cells. In addition, hind limb blood vessels and the liver could be visualized under a NIR camera by the fluorescence (wavelength: $1550 \mathrm{~nm}$ ) after intravenous injection, suggesting a simultaneous imaging and therapy for a "see and treat" approach. This technology may be applied to resolve the problem of poor penetration of antifungal agents for deep fungal stromal keratitis.

\section{Conclusions}

The results of in vitro investigations have demonstrated the potential of aPDT on fungal keratitis. Importantly, aPDT destroys fungal cells non-selectively. Thus, there have been no reports of PDT-resistance and/or cases of fungi becoming drug-resistant after aPDT treatments. Moreover, aPDT associated genotoxic or mutagenic effects to fungal or human cells have so far not been observed. Nonetheless, despite the success of many in vitro studies, animal studies and human trials are indispensable. At the time of the current review, RB appears to be a viable potential PS to treat fungal keratitis. A novel approach of PS delivery via the assistance of nanotechnology may be the next promising development for multidrug-resistant fungal keratitis.

Author Contributions: Conceptualization, J.-H.H., C.-N.L. and T.-W.W.; methodology, T.-W.W.; resources, I.-S.N., C.-J.W., C.-K.Y. and N.-Y.L.; writing-original draft preparation, J.-H.H., C.-N.L., H.-W.H., I.-S.N., C.-J.W., C.-K.Y., N.-Y.L., Y.C. and T.-W.W.; writing-review and editing, T.-W.W.; funding acquisition, J.-H.H., C.-N.L. and T.-W.W. All authors have read and agreed to the published version of the manuscript.

Funding: This work has received funding from the Center of Applied Nanomedicine, National Cheng Kung University from the Featured Areas Research Center Program within the framework of the Higher Education Sprout Project by the Ministry of Education (MOE), and Ministry of Science and Technology, Taiwan [MOST 109-2327-B-006-005] to TW Wong. J.H. Hung acknowledges funding from National Cheng Kung University Hospital, Taiwan [NCKUH-10802016 and NCKUH-11006018], and [MOST 110-2314-B-006-086-MY3].

Institutional Review Board Statement: Not applicable.

Informed Consent Statement: Not applicable.

Data Availability Statement: All data was presented in the manuscript.

Conflicts of Interest: The authors declare no conflict of interest.

\section{References}

1. Ting, D.S.J.; Ho, C.S.; Deshmukh, R.; Said, D.G.; Dua, H.S. Infectious keratitis: An update on epidemiology, causative microorganisms, risk factors, and antimicrobial resistance. Eye 2021, 35, 1084-1101. [CrossRef]

2. Ung, L.; Bispo, P.J.M.; Shanbhag, S.S.; Gilmore, M.S.; Chodosh, J. The persistent dilemma of microbial keratitis: Global burden, diagnosis, and antimicrobial resistance. Surv. Ophthalmol. 2019, 64, 255-271. [CrossRef] [PubMed] 
3. Khor, W.B.; Prajna, V.N.; Garg, P.; Mehta, J.S.; Xie, L.; Liu, Z.; Padilla, M.D.B.; Joo, C.K.; Inoue, Y.; Goseyarakwong, P.; et al. The Asia Cornea Society Infectious Keratitis Study: A prospective multicenter study of infectious keratitis in Asia. Am. J. Ophthalmol. 2018, 195, 161-170. [CrossRef]

4. Brown, L.; Leck, A.K.; Gichangi, M.; Burton, M.J.; Denning, D.W. The global incidence and diagnosis of fungal keratitis. Lancet Infect. Dis. 2021, 21, e49-e57. [CrossRef]

5. Lockhart, S.R.; Etienne, K.A.; Vallabhaneni, S.; Farooqi, J.; Chowdhary, A.; Govender, N.P.; Colombo, A.L.; Calvo, B.; Cuomo, C.A.; Desjardins, C.A.; et al. Simultaneous emergence of multidrug-resistant Candida auris on 3 continents confirmed by whole-genome sequencing and epidemiological analyses. Clin. Infect. Dis. 2017, 64, 134-140. [CrossRef] [PubMed]

6. Berman, J.; Krysan, D.J. Drug resistance and tolerance in fungi. Nat. Rev. Microbiol. 2020, 18, 319-331. [CrossRef]

7. Xie, L.; Dong, X.; Shi, W. Treatment of fungal keratitis by penetrating keratoplasty. Br. J. Ophthalmol. 2001, 85, 1070-1074. [CrossRef]

8. Kirkness, C.M.; Ficker, L.A.; Steele, A.D.; Rice, N.S. The role of penetrating keratoplasty in the management of microbial keratitis. Eye 1991, 5 Pt 4, 425-431. [CrossRef]

9. Tew, T.B.; Chu, H.S.; Hou, Y.C.; Chen, W.L.; Wang, I.J.; Hu, F.R. Therapeutic penetrating keratoplasty for microbial keratitis in Taiwan from 2001 to 2014. J. Formos. Med. Assoc. 2020, 119, 1061-1069. [CrossRef] [PubMed]

10. Moon, J.; Yoon, C.H.; Kim, M.K.; Oh, J.Y. The incidence and outcomes of recurrence of infection after therapeutic penetrating keratoplasty for medically-uncontrolled infectious keratitis. J. Clin. Med. 2020, 9, 3696. [CrossRef]

11. Vandeputte, P.; Ferrari, S.; Coste, A.T. Antifungal resistance and new strategies to control fungal infections. Int. J. Microbiol. 2012, 2012, 713687. [CrossRef] [PubMed]

12. Sara, S.; Sharpe, K.; Morris, S. Multidrug-resistant Fusarium keratitis: Diagnosis and treatment considerations. BMJ Case Rep. 2016, 2016, bcr2016215401. [CrossRef]

13. Lee, C.-N.; Hsu, R.; Chen, H.; Wong, T.-W. Daylight photodynamic therapy: An update. Molecules 2020, 25, 5195. [CrossRef] [PubMed]

14. Wainwright, M.; Maisch, T.; Nonell, S.; Plaetzer, K.; Almeida, A.; Tegos, G.P.; Hamblin, M.R. Photoantimicrobials—Are we afraid of the light? Lancet Infect. Dis. 2017, 17, e49-e55. [CrossRef]

15. Cieplik, F.; Deng, D.; Crielaard, W.; Buchalla, W.; Hellwig, E.; Al-Ahmad, A.; Maisch, T. Antimicrobial photodynamic therapyWhat we know and what we don't. Crit. Rev. Microbiol. 2018, 44, 571-589. [CrossRef] [PubMed]

16. Wong, T.-W.; Liao, S.-Z.; Ko, W.-C.; Wu, C.-J.; Wu, S.B.; Chuang, Y.-C.; Huang, I.H. Indocyanine green-mediated photodynamic therapy reduces Methicillin-resistant Staphylococcus aureus drug resistance. J. Clin. Med. 2019, 8, 411. [CrossRef] [PubMed]

17. Newman, D.K. Photodynamic therapy: Current role in the treatment of chorioretinal conditions. Eye 2016, 30, 202-210. [CrossRef]

18. Wollensak, G.; Spoerl, E.; Seiler, T. Riboflavin/ultraviolet-a-induced collagen crosslinking for the treatment of keratoconus. Am. J. Ophthalmol. 2003, 135, 620-627. [CrossRef]

19. Iseli, H.P.; Thiel, M.A.; Hafezi, F.; Kampmeier, J.; Seiler, T. Ultraviolet A/riboflavin corneal cross-linking for infectious keratitis associated with corneal melts. Cornea 2008, 27, 590-594. [CrossRef]

20. Naranjo, A.; Arboleda, A.; Martinez, J.D.; Durkee, H.; Aguilar, M.C.; Relhan, N.; Nikpoor, N.; Galor, A.; Dubovy, S.R.; Leblanc, R.; et al. Rose bengal photodynamic antimicrobial therapy for patients with progressive infectious keratitis: A pilot clinical study. Am. J. Ophthalmol. 2019, 208, 387-396. [CrossRef]

21. Altamirano, D.; Martinez, J.; Leviste, K.D.; Parel, J.M.; Amescua, G. Photodynamic therapy for infectious keratitis. Curr. Ophthalmol. Rep. 2020, 8, 245-251. [CrossRef] [PubMed]

22. Thomas, P.A.; Kaliamurthy, J. Mycotic keratitis: Epidemiology, diagnosis and management. Clin. Microbiol. Infect 2013, 19, 210-220. [CrossRef] [PubMed]

23. Mahmoudi, S.; Masoomi, A.; Ahmadikia, K.; Tabatabaei, S.A.; Soleimani, M.; Rezaie, S.; Ghahvechian, H.; Banafsheafshan, A. Fungal keratitis: An overview of clinical and laboratory aspects. Mycoses 2018, 61, 916-930. [CrossRef]

24. Austin, A.; Lietman, T.; Rose-Nussbaumer, J. Update on the management of infectious keratitis. Ophthalmology 2017, 124, 1678-1689. [CrossRef] [PubMed]

25. Słowik, M.; Biernat, M.M.; Urbaniak-Kujda, D.; Kapelko-Słowik, K.; Misiuk-Hojło, M. Mycotic Infections of the Eye. Adv. Clin. Exp. Med. 2015, 24, 1113-1117. [CrossRef]

26. Walther, G.; Stasch, S.; Kaerger, K.; Hamprecht, A.; Roth, M.; Cornely, O.A.; Geerling, G.; Mackenzie, C.R.; Kurzai, O.; von Lilienfeld-Toal, M. Fusarium keratitis in Germany. J. Clin. Microbiol. 2017, 55, 2983-2995. [CrossRef]

27. Oliveira Dos Santos, C.; Kolwijck, E.; van der Lee, H.A.; Tehupeiory-Kooreman, M.C.; Al-Hatmi, A.M.S.; Matayan, E.; Burton, M.J.; Eggink, C.A.; Verweij, P.E. In vitro activity of chlorhexidine compared with seven antifungal agents against 98 fusarium isolates recovered from fungal keratitis patients. Antimicrob. Agents Chemother. 2019, 63, e02669-18. [CrossRef]

28. Kalaiselvi, G.; Narayana, S.; Krishnan, T.; Sengupta, S. Intrastromal voriconazole for deep recalcitrant fungal keratitis: A case series. Br. J. Ophthalmol. 2015, 99, 195-198. [CrossRef]

29. Sun, R.L.; Jones, D.B.; Wilhelmus, K.R. Clinical characteristics and outcome of Candida keratitis. Am. J. Ophthalmol. 2007, 143, 1043-1045. [CrossRef]

30. Perlin, D.S.; Rautemaa-Richardson, R.; Alastruey-Izquierdo, A. The global problem of antifungal resistance: Prevalence, mechanisms, and management. Lancet Infect. Dis. 2017, 17, e383-e392. [CrossRef] 
31. Sponsel, W.E.; Graybill, J.R.; Nevarez, H.L.; Dang, D. Ocular and systemic posaconazole(SCH-56592) treatment of invasive Fusarium solani keratitis and endophthalmitis. Br. J. Ophthalmol. 2002, 86, 829-830. [CrossRef]

32. Antequera, P.; Garcia-Conca, V.; Martín-González, C.; Ortiz-de-la-Tabla, V. Multidrug resistant Fusarium keratitis. Arch. Soc. Esp . Oftalmol. 2015, 90, 382-384. [CrossRef] [PubMed]

33. Tupaki-Sreepurna, A.; Al-Hatmi, A.M.; Kindo, A.J.; Sundaram, M.; de Hoog, G.S. Multidrug-resistant Fusarium in keratitis: A clinico-mycological study of keratitis infections in Chennai, India. Mycoses 2017, 60, 230-233. [CrossRef]

34. Vermitsky, J.-P.; Edlind, T.D. Azole resistance in Candida glabrata: Coordinate upregulation of multidrug transporters and evidence for a Pdr1-like transcription factor. Antimicrob. Agents Chemother. 2004, 48, 3773-3781. [CrossRef]

35. Costa-de-Oliveira, S.; Rodrigues, A.G. Candida albicans antifungal resistance and tolerance in bloodstream infections: The triad yeast-host-antifungal. Microorganisms 2020, 8, 154. [CrossRef] [PubMed]

36. Cowen, L.E.; Sanglard, D.; Howard, S.J.; Rogers, P.D.; Perlin, D.S. Mechanisms of antifungal drug resistance. Cold Spring Harb. Perspect. Med. 2014, 5, a019752. [CrossRef] [PubMed]

37. Gallagher, J.C.; Dodds Ashley, E.S.; Drew, R.H.; Perfect, J.R. Antifungal pharmacotherapy for invasive mould infections. Expert Opin. Pharm. 2003, 4, 147-164. [CrossRef] [PubMed]

38. Zonios, D.I.; Bennett, J.E. Update on azole antifungals. Semin. Respir. Crit. Care Med. 2008, 29, 198-210. [CrossRef] [PubMed]

39. Pappas, P.G.; Kauffman, C.A.; Andes, D.R.; Clancy, C.J.; Marr, K.A.; Ostrosky-Zeichner, L.; Reboli, A.C.; Schuster, M.G.; Vazquez, J.A.; Walsh, T.J.; et al. Clinical practice guideline for the management of Candidiasis: 2016 update by the Infectious Diseases Society of America. Clin. Infect. Dis. 2016, 62, e1-e50. [CrossRef]

40. Denning, D.W. Echinocandin antifungal drugs. Lancet 2003, 362, 1142-1151. [CrossRef]

41. Kaur, S.; Singh, S. Biofilm formation by Aspergillus fumigatus. Med. Mycol. 2014, 52, 2-9. [CrossRef]

42. Donlan, R.M. Biofilms: Microbial life on surfaces. Emerg. Infect. Dis. 2002, 8, 881-890. [CrossRef] [PubMed]

43. Pierce, C.G.; Srinivasan, A.; Uppuluri, P.; Ramasubramanian, A.K.; López-Ribot, J.L. Antifungal therapy with an emphasis on biofilms. Curr. Opin. Pharmacol. 2013, 13, 726-730. [CrossRef] [PubMed]

44. Córdova-Alcántara, I.M.; Venegas-Cortés, D.L.; Martínez-Rivera, M.; Pérez, N.O.; Rodriguez-Tovar, A.V. Biofilm characterization of Fusarium solani keratitis isolate: Increased resistance to antifungals and UV light. J. Microbiol. 2019, 57, 485-497. [CrossRef]

45. Nobile, C.J.; Johnson, A.D. Candida albicans biofilms and human disease. Annu. Rev. Microbiol. 2015, 69, 71-92. [CrossRef] [PubMed]

46. Mukherjee, P.K.; Chandra, J.; Yu, C.; Sun, Y.; Pearlman, E.; Ghannoum, M.A. Characterization of fusarium keratitis outbreak isolates: Contribution of biofilms to antimicrobial resistance and pathogenesis. Investig. Ophthalmol. Vis. Sci. 2012, 53, $4450-4457$. [CrossRef]

47. Delattin, N.; Cammue, B.P.; Thevissen, K. Reactive oxygen species-inducing antifungal agents and their activity against fungal biofilms. Future Med. Chem. 2014, 6, 77-90. [CrossRef]

48. Nagy, F.; Tóth, Z.; Daróczi, L.; Székely, A.; Borman, A.M.; Majoros, L.; Kovács, R. Farnesol increases the activity of echinocandins against Candida auris biofilms. Med. Mycol. 2020, 58, 404-407. [CrossRef] [PubMed]

49. Perez-Laguna, V.; Gilaberte, Y.; Millan-Lou, M.I.; Agut, M.; Nonell, S.; Rezusta, A.; Hamblin, M.R. A combination of photodynamic therapy and antimicrobial compounds to treat skin and mucosal infections: A systematic review. Photochem. Photobiol. Sci. 2019, 18, 1020-1029. [CrossRef]

50. Sengupta, J.; Saha, S.; Khetan, A.; Sarkar, S.K.; Mandal, S.M. Effects of lactoferricin B against keratitis-associated fungal biofilms. J. Infect. Chemother. 2012, 18, 698-703. [CrossRef]

51. Zacchino, S.A.; Butassi, E.; Cordisco, E.; Svetaz, L.A. Hybrid combinations containing natural products and antimicrobial drugs that interfere with bacterial and fungal biofilms. Phytomedicine 2017, 37, 14-26. [CrossRef]

52. Cepas, V.; López, Y.; Gabasa, Y.; Martins, C.B.; Ferreira, J.D.; Correia, M.J.; Santos, L.M.A.; Oliveira, F.; Ramos, V.; Reis, M.; et al. Inhibition of bacterial and fungal biofilm formation by 675 extracts from microalgae and cyanobacteria. Antibiotics $2019,8,77$. [CrossRef] [PubMed]

53. Guarro, J.; Rubio, C.; Gené, J.; Cano, J.; Gil, J.; Benito, R.; Moranderia, M.J.; Miguez, E. Case of keratitis caused by an uncommon Fusarium species. J. Clin. Microbiol. 2003, 41, 5823-5826. [CrossRef] [PubMed]

54. Tu, E.Y.; McCartney, D.L.; Beatty, R.F.; Springer, K.L.; Levy, J.; Edward, D. Successful treatment of resistant ocular fusariosis with posaconazole (SCH-56592). Am. J. Ophthalmol. 2007, 143, 222-227.e221. [CrossRef] [PubMed]

55. Proença-Pina, J.; Ssi Yan Kai, I.; Bourcier, T.; Fabre, M.; Offret, H.; Labetoulle, M. Fusarium keratitis and endophthalmitis associated with lens contact wear. Int. Ophthalmol. 2010, 30, 103-107. [CrossRef]

56. Edelstein, S.L.; Akduman, L.; Durham, B.H.; Fothergill, A.W.; Hsu, H.Y. Resistant Fusarium keratitis progressing to endophthalmitis. Eye Contact Lens 2012, 38, 331-335. [CrossRef]

57. Vecchio, D.; Dai, T.; Huang, L.; Fantetti, L.; Roncucci, G.; Hamblin, M.R. Antimicrobial photodynamic therapy with RLP068 kills methicillin-resistant Staphylococcus aureus and improves wound healing in a mouse model of infected skin abrasion PDT with $\mathrm{RLP068/Cl}$ in infected mouse skin abrasion. J. Biophotonics 2013, 6, 733-742. [CrossRef]

58. Kashef, N.; Akbarizare, M.; Kamrava, S.K. Effect of sub-lethal photodynamic inactivation on the antibiotic susceptibility and biofilm formation of clinical Staphylococcus aureus isolates. Photodiagn. Photodyn. Ther. 2013, 10, 368-373. [CrossRef]

59. Ethirajan, M.; Chen, Y.; Joshi, P.; Pandey, R.K. The role of porphyrin chemistry in tumor imaging and photodynamic therapy. Chem. Soc. Rev. 2011, 40, 340-362. [CrossRef] 
60. Jeon, Y.M.; Lee, H.S.; Jeong, D.; Oh, H.K.; Ra, K.H.; Lee, M.Y. Antimicrobial photodynamic therapy using chlorin e6 with halogen light for acne bacteria-induced inflammation. Life Sci. 2015, 124, 56-63. [CrossRef]

61. Fekrazad, R.; Ghasemi Barghi, V.; Poorsattar Bejeh Mir, A.; Shams-Ghahfarokhi, M. In vitro photodynamic inactivation of Candida albicans by phenothiazine dye (new methylene blue) and indocyanine green (EmunDo ${ }^{\circledR}$ ). Photodiagn. Photodyn. Ther. 2015, 12, 52-57. [CrossRef] [PubMed]

62. Maisch, T.; Eichner, A.; Späth, A.; Gollmer, A.; König, B.; Regensburger, J.; Bäumler, W. Fast and effective photodynamic inactivation of multiresistant bacteria by cationic riboflavin derivatives. PLoS ONE 2014, 9, e111792. [CrossRef]

63. Maisch, T.; Bosl, C.; Szeimies, R.M.; Lehn, N.; Abels, C. Photodynamic effects of novel XF porphyrin derivatives on prokaryotic and eukaryotic cells. Antimicrob. Agents Chemother. 2005, 49, 1542-1552. [CrossRef]

64. Mizuno, K.; Zhiyentayev, T.; Huang, L.; Khalil, S.; Nasim, F.; Tegos, G.P.; Gali, H.; Jahnke, A.; Wharton, T.; Hamblin, M.R. Antimicrobial photodynamic therapy with functionalized fullerenes: Quantitative structure-activity relationships. J. Nanomed. Nanotechnol. 2011, 2, 1-9. [CrossRef] [PubMed]

65. Topaloglu, N.; Gulsoy, M.; Yuksel, S. Antimicrobial photodynamic therapy of resistant bacterial strains by indocyanine green and 809-nm diode laser. Photomed. Laser Surg. 2013, 31, 155-162. [CrossRef]

66. Cieplik, F.; Späth, A.; Regensburger, J.; Gollmer, A.; Tabenski, L.; Hiller, K.A.; Bäumler, W.; Maisch, T.; Schmalz, G. Photodynamic biofilm inactivation by SAPYR-an exclusive singlet oxygen photosensitizer. Free Radic. Biol. Med. 2013, 65, 477-487. [CrossRef]

67. Tortik, N.; Steinbacher, P.; Maisch, T.; Spaeth, A.; Plaetzer, K. A comparative study on the antibacterial photodynamic efficiency of a curcumin derivative and a formulation on a porcine skin model. Photochem. Photobiol. Sci. 2016, 15, 187-195. [CrossRef]

68. Ricci Donato, H.A.; Pratavieira, S.; Grecco, C.; Brugnera-Júnior, A.; Bagnato, V.S.; Kurachi, C. Clinical comparison of two photosensitizers for oral cavity decontamination. Photomed. Laser Surg. 2017, 35, 105-110. [CrossRef] [PubMed]

69. Fisher, C.J.; Niu, C.; Foltz, W.; Chen, Y.; Sidorova-Darmos, E.; Eubanks, J.H.; Lilge, L. ALA-PpIX mediated photodynamic therapy of malignant gliomas augmented by hypothermia. PLOS ONE 2017, 12, e0181654. [CrossRef]

70. Morley, S.; Griffiths, J.; Philips, G.; Moseley, H.; O'Grady, C.; Mellish, K.; Lankester, C.L.; Faris, B.; Young, R.J.; Brown, S.B.; et al. Phase IIa randomized, placebo-controlled study of antimicrobial photodynamic therapy in bacterially colonized, chronic leg ulcers and diabetic foot ulcers: A new approach to antimicrobial therapy. Br. J. Dermatol. 2013, 168, 617-624. [CrossRef]

71. Lee, H.J.; Kang, S.M.; Jeong, S.H.; Chung, K.H.; Kim, B.I. Antibacterial photodynamic therapy with curcumin and Curcuma xanthorrhiza extract against Streptococcus mutans. Photodiagn. Photodyn. Ther. 2017, 20, 116-119. [CrossRef] [PubMed]

72. Donnelly, R.F.; McCarron, P.A.; Tunney, M.M. Antifungal photodynamic therapy. Microbiol. Res. 2008, 163, 1-12. [CrossRef]

73. Baltazar, L.M.; Ray, A.; Santos, D.A.; Cisalpino, P.S.; Friedman, A.J.; Nosanchuk, J.D. Antimicrobial photodynamic therapy: An effective alternative approach to control fungal infections. Front. Microbiol. 2015, 6, 202. [CrossRef] [PubMed]

74. Su, G.; Wei, Z.; Wang, L.; Shen, J.; Baudouin, C.; Labbé, A.; Liang, Q. Evaluation of toluidine blue-mediated photodynamic therapy for experimental bacterial keratitis in rabbits. Transl. Vis. Sci. Technol. 2020, 9, 13. [CrossRef] [PubMed]

75. Shih, M.H.; Huang, F.C. Effects of photodynamic therapy on rapidly growing nontuberculous mycobacteria keratitis. Investig. Ophthalmol. Vis. Sci. 2011, 52, 223-229. [CrossRef]

76. Halili, F.; Arboleda, A.; Durkee, H.; Taneja, M.; Miller, D.; Alawa, K.A.; Aguilar, M.C.; Amescua, G.; Flynn, H.W., Jr.; Parel, J.M. Rose bengal- and riboflavin-mediated photodynamic therapy to inhibit Methicillin-resistant Staphylococcus aureus keratitis isolates. Am. J. Ophthalmol. 2016, 166, 194-202. [CrossRef]

77. Arboleda, A.; Miller, D.; Cabot, F.; Taneja, M.; Aguilar, M.C.; Alawa, K.; Amescua, G.; Yoo, S.H.; Parel, J.M. Assessment of rose bengal versus riboflavin photodynamic therapy for inhibition of fungal keratitis isolates. Am. J. Ophthalmol. 2014, 158, 64-70.e62. [CrossRef]

78. Ito, T. Photodynamic action of hematoporphyrin on yeast cells-a kinetic approach. Photochem. Photobiol. 1981, 34, 521-524. [CrossRef]

79. Carré, V.; Gaud, O.; Sylvain, I.; Bourdon, O.; Spiro, M.; Biais, J.; Granet, R.; Krausz, P.; Guilloton, M. Fungicidal properties of meso-arylglycosylporphyrins: Influence of sugar substituents on photoinduced damage in the yeast Saccharomyces cerevisiœ. J. Photochem. Photobiol. B Biol. 1999, 48, 57-62. [CrossRef]

80. Voit, T.; Cieplik, F.; Regensburger, J.; Hiller, K.A.; Gollmer, A.; Buchalla, W.; Maisch, T. Spatial distribution of a porphyrin-based photosensitizer reveals mechanism of photodynamic inactivation of Candida albicans. Front. Med. 2021, 8, 641244. [CrossRef]

81. Zoładek, T.; Nguyen, B.N.; Jagiełło, I.; Graczyk, A.; Rytka, J. Diamino acid derivatives of porphyrins penetrate into yeast cells, induce photodamage, but have no mutagenic effect. Photochem. Photobiol. 1997, 66, 253-259. [CrossRef]

82. Baskaran, R.; Lee, J.; Yang, S.-G. Clinical development of photodynamic agents and therapeutic applications. Biomater. Res. 2018, 22, 25. [CrossRef]

83. Paardekooper, M.; Van den Broek, P.J.; De Bruijne, A.W.; Elferink, J.G.; Dubbelman, T.M.; Van Steveninck, J. Photodynamic treatment of yeast cells with the dye toluidine blue: All-or-none loss of plasma membrane barrier properties. Biochim. Biophys. Acta 1992, 1108, 86-90. [CrossRef]

84. de Souza, S.C.; Junqueira, J.C.; Balducci, I.; Koga-Ito, C.Y.; Munin, E.; Jorge, A.O. Photosensitization of different Candida species by low power laser light. J. Photochem. Photobiol. B 2006, 83, 34-38. [CrossRef]

85. Demidova, T.N.; Hamblin, M.R. Effect of cell-photosensitizer binding and cell density on microbial photoinactivation. Antimicrob. Agents Chemother. 2005, 49, 2329-2335. [CrossRef] 
86. Giroldo, L.M.; Felipe, M.P.; de Oliveira, M.A.; Munin, E.; Alves, L.P.; Costa, M.S. Photodynamic antimicrobial chemotherapy (PACT) with methylene blue increases membrane permeability in Candida albicans. Lasers Med. Sci. 2009, 24, 109-112. [CrossRef] [PubMed]

87. Güzel Tunçcan, Ö.; Kalkancı, A.; Unal, E.A.; Abdulmajed, O.; Erdoğan, M.; Dizbay, M.; Çağlar, K. The in vitro effect of antimicrobial photodynamic therapy on Candida and Staphylococcus biofilms. Turk. J. Med. Sci. 2018, 48, 873-879. [CrossRef] [PubMed]

88. Sridharan, G.; Shankar, A.A. Toluidine blue: A review of its chemistry and clinical utility. J. Oral Maxillofac. Pathol. 2012, 16, 251-255. [CrossRef] [PubMed]

89. Wainwright, M. Photodynamic antimicrobial chemotherapy (PACT). J. Antimicrob. Chemother. 1998, 42, 13-28. [CrossRef] [PubMed]

90. Wiench, R.; Skaba, D.; Matys, J.; Grzech-Lesniak, K. Efficacy of toluidine blue-mediated antimicrobial photodynamic therapy on Candida spp. a systematic review. Antibiotics 2021, 10, 349. [CrossRef]

91. Brouillet, N.; Arselin-De Chateaubodeau, G.; Volland, C. Studies on protoporphyrin biosynthetic pathway in Saccharomyces cerevisiae; characterization of the tetrapyrrole intermediates. Biochimie 1975, 57, 647-655. [CrossRef]

92. Strakhovskaya, M.G.; Shumarina, A.O.; Fraikin, G.Y.; Rubin, A.B. Synthesis of protoporphyrin IX induced by 5-aminolevulinic acid in yeast cells in the presence of 2,2;-dipyridyl. Biochemistry 1998, 63, 725-728.

93. Monfrecola, G.; Procaccini, E.M.; Bevilacqua, M.; Manco, A.; Calabro, G.; Santoianni, P. In vitro effect of 5-aminolaevulinic acid plus visible light on Candida albicans. Photochem. Photobiol. Sci. 2004, 3, 419-422. [CrossRef] [PubMed]

94. Kato, I.T.; Prates, R.A.; Sabino, C.P.; Fuchs, B.B.; Tegos, G.P.; Mylonakis, E.; Hamblin, M.R.; Ribeiro, M.S. Antimicrobial photodynamic inactivation inhibits Candida albicans virulence factors and reduces in vivo pathogenicity. Antimicrob. Agents Chemother. 2013, 57, 445-451. [CrossRef]

95. Huang, X.; Xu, M.; Pan, W.; Wang, M.; Wu, X.; Dai, S.; Li, L.; Zeng, K. Antimicrobial and immunomodulatory responses of photodynamic therapy in Galleria mellonella model. BMC Microbiol. 2020, 20, 196. [CrossRef] [PubMed]

96. Shi, H.; Li, J.; Zhang, H.; Zhang, J.; Sun, H. Effect of 5-aminolevulinic acid photodynamic therapy on Candida albicans biofilms: An in vitro study. Photodiagn. Photodyn. Ther. 2016, 15, 40-45. [CrossRef]

97. Lomax, S.Q. Phthalocyanine and quinacridone pigments: Their history, properties and use. Stud. Conserv. 2005, 50, 19-29. [CrossRef]

98. Berg, K.; Bommer, J.C.; Moan, J. Evaluation of sulfonated aluminum phthalocyanines for use in photochemotherapy. A study on the relative efficiencies of photoinactivation. Photochem. Photobiol. 1989, 49, 587-594. [CrossRef] [PubMed]

99. Bertoloni, G.; Rossi, F.; Valduga, G.; Jori, G.; Ali, H.; van Lier, J.E. Photosensitizing activity of water- and lipid-soluble phthalocyanines on prokaryotic and eukaryotic microbial cells. Microbios 1992, 71, 33-46.

100. Ozturk, I.; Tunçel, A.; Lambrecht, F.; Bıyıklığlu, Z.; Ince, M.; Ocakoglu, K. Antifungal photodynamic activities of phthalocyanine derivatives on Candida albicans. Photodiagn. Photodyn. Ther. 2020, 30, 101715. [CrossRef]

101. Lo, P.C.; Rodriguez-Morgade, M.S.; Pandey, R.K.; Ng, D.K.P.; Torres, T.; Dumoulin, F. The unique features and promises of phthalocyanines as advanced photosensitisers for photodynamic therapy of cancer. Chem. Soc. Rev. 2020, 49, 1041-1056. [CrossRef]

102. Jeng, B.H.; Farid, M.; Patel, S.V.; Schwab, I.R. Corneal cross-linking for keratoconus: A look at the data, the food and drug administration, and the future. Ophthalmology 2016, 123, 2270-2272. [CrossRef]

103. Salomão, M.Q.; Hofling-Lima, A.L.; Gomes Esporcatte, L.P.; Correa, F.F.; Lopes, B.; Sena, N., Jr.; Dawson, D.G.; Ambrósio, R., Jr. Ectatic diseases. Exp. Eye Res. 2021, 202, 108347. [CrossRef]

104. McCall, A.S.; Kraft, S.; Edelhauser, H.F.; Kidder, G.W.; Lundquist, R.R.; Bradshaw, H.E.; Dedeic, Z.; Dionne, M.J.; Clement, E.M.; Conrad, G.W. Mechanisms of corneal tissue cross-linking in response to treatment with topical riboflavin and long-wavelength ultraviolet radiation (UVA). Investig. Ophthalmol. Vis. Sci. 2010, 51, 129-138. [CrossRef]

105. Spoerl, E.; Huhle, M.; Seiler, T. Induction of cross-links in corneal tissue. Exp. Eye Res. 1998, 66, 97-103. [CrossRef]

106. Meek, K.M.; Hayes, S. Corneal cross-linking-A review. Ophthalmic Physiol. Opt. 2013, 33, 78-93. [CrossRef] [PubMed]

107. Chan, T.C.; Lau, T.W.; Lee, J.W.; Wong, I.Y.; Jhanji, V.; Wong, R.L. Corneal collagen cross-linking for infectious keratitis: An update of clinical studies. Acta Ophthalmol. 2015, 93, 689-696. [CrossRef]

108. Prajna, N.V.; Radhakrishnan, N.; Lalitha, P.; Austin, A.; Ray, K.J.; Keenan, J.D.; Porco, T.C.; Lietman, T.M.; Rose-Nussbaumer, J. Cross-linking-assisted infection reduction: A randomized clinical trial evaluating the effect of adjuvant cross-linking on outcomes in fungal keratitis. Ophthalmology 2020, 127, 159-166. [CrossRef] [PubMed]

109. Tabibian, D.; Richoz, O.; Hafezi, F. PACK-CXL: Corneal cross-linking for treatment of infectious keratitis. J. Ophthalmic Vis. Res. 2015, 10, 77-80. [CrossRef] [PubMed]

110. Martins, S.A.; Combs, J.C.; Noguera, G.; Camacho, W.; Wittmann, P.; Walther, R.; Cano, M.; Dick, J.; Behrens, A. Antimicrobial efficacy of riboflavin/UVA combination $(365 \mathrm{~nm})$ in vitro for bacterial and fungal isolates: A potential new treatment for infectious keratitis. Investig. Ophthalmol. Vis. Sci. 2008, 49, 3402-3408. [CrossRef]

111. Said, D.G.; Elalfy, M.S.; Gatzioufas, Z.; El-Zakzouk, E.S.; Hassan, M.A.; Saif, M.Y.; Zaki, A.A.; Dua, H.S.; Hafezi, F. Collagen cross-linking with photoactivated riboflavin (PACK-CXL) for the treatment of advanced infectious keratitis with corneal melting Ophthalmology 2014, 121, 1377-1382. [CrossRef] [PubMed] 
112. Price, M.O.; Tenkman, L.R.; Schrier, A.; Fairchild, K.M.; Trokel, S.L.; Price, F.W., Jr. Photoactivated riboflavin treatment of infectious keratitis using collagen cross-linking technology. J. Refract. Surg. 2012, 28, 706-713. [CrossRef]

113. Makdoumi, K.; Mortensen, J.; Sorkhabi, O.; Malmvall, B.E.; Crafoord, S. UVA-riboflavin photochemical therapy of bacterial keratitis: A pilot study. Graefes Arch. Clin. Exp. Ophthalmol. 2012, 250, 95-102. [CrossRef]

114. Prajna, N.V.; Radhakrishnan, N.; Lalitha, P.; Rajaraman, R.; Narayana, S.; Austin, A.F.; Liu, Z.; Keenan, J.D.; Porco, T.C.; Lietman, T.M.; et al. Cross-linking assisted infection reduction (CLAIR): A randomized clinical trial evaluating the effect of adjuvant cross-linking on bacterial keratitis. Cornea 2020, 40, 837-841. [CrossRef] [PubMed]

115. Uddaraju, M.; Mascarenhas, J.; Das, M.R.; Radhakrishnan, N.; Keenan, J.D.; Prajna, L.; Prajna, V.N. Corneal cross-linking as an adjuvant therapy in the management of recalcitrant deep stromal fungal keratitis: A randomized trial. Am. J. Ophthalmol. 2015, 160, 131-134.e135. [CrossRef]

116. Vajpayee, R.B.; Shafi, S.N.; Maharana, P.K.; Sharma, N.; Jhanji, V. Evaluation of corneal collagen cross-linking as an additional therapy in mycotic keratitis. Clin. Exp. Ophthalmol. 2015, 43, 103-107. [CrossRef] [PubMed]

117. Kasetsuwan, N.; Reinprayoon, U.; Satitpitakul, V. Photoactivated chromophore for moderate to severe infectious keratitis as an adjunct therapy: A randomized controlled trial. Am. J. Ophthalmol. 2016, 165, 94-99. [CrossRef]

118. Mikropoulos, D.G.; Kymionis, G.D.; Voulgari, N.; Kaisari, E.; Nikolakopoulos, K.A.; Katsanos, A.; Konstas, A.G. Intraoperative photoactivated chromophore for infectious keratitis-corneal cross-linking (PACK-CXL) during penetrating keratoplasty for the management of fungal keratitis in an immunocompromised patient. Ophthalmol. Ther. 2019, 8, 491-495. [CrossRef] [PubMed]

119. Marshall, P.N. The composition of erythrosins, fluorescein, phloxine and rose bengal: A study using thin-layer chromatography and solvent extraction. Histochem. J. 1976, 8, 487-499. [CrossRef]

120. Feenstra, R.P.; Tseng, S.C. Comparison of fluorescein and rose bengal staining. Ophthalmology 1992, 99, 605-617. [CrossRef]

121. Lazarova, G. Effect of glutathione on rose bengal photosensitized yeast damage. Microbios 1993, 75, 39-43.

122. Amescua, G.; Arboleda, A.; Nikpoor, N.; Durkee, H.; Relhan, N.; Aguilar, M.C.; Flynn, H.W.; Miller, D.; Parel, J.M. Rose bengal photodynamic antimicrobial therapy: A novel treatment for resistant fusarium keratitis. Cornea 2017, 36, 1141-1144. [CrossRef] [PubMed]

123. Costa, A.C.; Rasteiro, V.M.; Pereira, C.A.; Rossoni, R.D.; Junqueira, J.C.; Jorge, A.O. The effects of rose bengal- and erythrosinemediated photodynamic therapy on Candida albicans. Mycoses 2012, 55, 56-63. [CrossRef] [PubMed]

124. Cherfan, D.; Verter, E.E.; Melki, S.; Gisel, T.E.; Doyle, F.J., Jr.; Scarcelli, G.; Yun, S.H.; Redmond, R.W.; Kochevar, I.E. Collagen cross-linking using rose bengal and green light to increase corneal stiffness. Investig. Ophthalmol. Vis. Sci. 2013, 54, $3426-3433$. [CrossRef] [PubMed]

125. Wertheimer, C.M.; Mendes, B.; Pei, Q.; Brandt, K.; Kochevar, I.E. Arginine as an enhancer in rose bengal photosensitized corneal crosslinking. Transl. Vis. Sci. Technol. 2020, 9, 24. [CrossRef]

126. Santhiago, M.R.; Randleman, J.B. The biology of corneal cross-linking derived from ultraviolet light and riboflavin. Exp. Eye Res. 2021, 202, 108355. [CrossRef]

127. Fadlallah, A.; Zhu, H.; Arafat, S.; Kochevar, I.; Melki, S.; Ciolino, J.B. Corneal resistance to keratolysis after collagen crosslinking with rose bengal and green light. Investig. Ophthalmol. Vis. Sci. 2016, 57, 6610-6614. [CrossRef]

128. Martinez, J.D.; Naranjo, A.; Amescua, G.; Dubovy, S.R.; Arboleda, A.; Durkee, H.; Aguilar, M.C.; Flynn, H.W.; Miller, D.; Parel, J.M. Human corneal changes after rose bengal photodynamic antimicrobial therapy for treatment of fungal keratitis. Cornea 2018, 37, e46-e48. [CrossRef]

129. Peterson, J.C.; Arrieta, E.; Ruggeri, M.; Silgado, J.D.; Mintz, K.J.; Weisson, E.H.; Leblanc, R.M.; Kochevar, I.; Manns, F.; Parel, J.M. Detection of singlet oxygen luminescence for experimental corneal rose bengal photodynamic antimicrobial therapy. Biomed. Opt. Express 2021, 12, 272-287. [CrossRef]

130. de Melo, W.C.; Avci, P.; de Oliveira, M.N.; Gupta, A.; Vecchio, D.; Sadasivam, M.; Chandran, R.; Huang, Y.Y.; Yin, R.; Perussi, L.R.; et al. Photodynamic inactivation of biofilm: Taking a lightly colored approach to stubborn infection. Expert Rev. Anti-Infect. Ther. 2013, 11, 669-693. [CrossRef]

131. Costa, A.C.; de Campos Rasteiro, V.M.; Pereira, C.A.; da Silva Hashimoto, E.S.; Beltrame, M., Jr.; Junqueira, J.C.; Jorge, A.O. Susceptibility of Candida albicans and Candida dubliniensis to erythrosine- and LED-mediated photodynamic therapy. Arch. Oral Biol. 2011, 56, 1299-1305. [CrossRef]

132. Silva, M.P.; dos Santos, T.A.; de Barros, P.P.; de Camargo Ribeiro, F.; Junqueira, J.C.; Jorge, A.O. Action of antimicrobial photodynamic therapy on heterotypic biofilm: Candida albicans and Bacillus atrophaeus. Lasers Med. Sci. 2016, 31, 605-610. [CrossRef] [PubMed]

133. Warrier, A.; Mazumder, N.; Prabhu, S.; Satyamoorthy, K.; Murali, T.S. Photodynamic therapy to control microbial biofilms. Photodiagn. Photodyn. Ther. 2021, 33, 102090. [CrossRef]

134. Akpek, E.K.; Gottsch, J.D. Immune defense at the ocular surface. Eye 2003, 17, 949-956. [CrossRef] [PubMed]

135. Moiseev, R.V.; Morrison, P.W.J.; Steele, F.; Khutoryanskiy, V.V. Penetration enhancers in ocular drug delivery. Pharmaceutics 2019, 11, 321. [CrossRef]

136. Jumelle, C.; Gholizadeh, S.; Annabi, N.; Dana, R. Advances and limitations of drug delivery systems formulated as eye drops. J. Control. Release 2020, 321, 1-22. [CrossRef] [PubMed] 
137. Mastropasqua, L.; Nubile, M.; Calienno, R.; Mattei, P.A.; Pedrotti, E.; Salgari, N.; Mastropasqua, R.; Lanzini, M. Corneal cross-linking: Intrastromal riboflavin concentration in iontophoresis-assisted imbibition versus traditional and transepithelial techniques. Am. J. Ophthalmol. 2014, 157, 623-630.e621. [CrossRef]

138. Lamy, R.; Chan, E.; Zhang, H.; Salgaonkar, V.A.; Good, S.D.; Porco, T.C.; Diederich, C.J.; Stewart, J.M. Ultrasound-enhanced penetration of topical riboflavin into the corneal stroma. Investig. Ophthalmol. Vis. Sci. 2013, 54, 5908-5912. [CrossRef]

139. Tefon Aribas, A.B.; Sarikaya, B.; Bilgihan, K. Iontophoresis-assisted rose bengal and green light corneal cross-linking. Cornea 2020, 39, 1533-1540. [CrossRef]

140. Wu, H.; Li, L.; Luo, S.; Fang, X.; Shang, X.; Xie, Z.; Xiao, X.; He, H.; Lin, Z.; Liu, Z. Safety and efficacy of repeated crosslinking assisted by transepithelial double-cycle iontophoresis in keratoconus progression after primary corneal crosslinking. Eye 2021, 35, 3020-3027. [CrossRef]

141. Ustundag Okur, N.; Caglar, E.S.; Siafaka, P.I. Novel ocular drug delivery systems: An update on microemulsions. J. Ocul. Pharmacol. Ther. 2020, 36, 342-354. [CrossRef]

142. Lalu, L.; Tambe, V.; Pradhan, D.; Nayak, K.; Bagchi, S.; Maheshwari, R.; Kalia, K.; Tekade, R.K. Novel nanosystems for the treatment of ocular inflammation: Current paradigms and future research directions. J. Control. Release 2017, 268, 19-39. [CrossRef]

143. Ikuta, Y.; Aoyagi, S.; Tanaka, Y.; Sato, K.; Inada, S.; Koseki, Y.; Onodera, T.; Oikawa, H.; Kasai, H. Creation of nano eye-drops and effective drug delivery to the interior of the eye. Sci. Rep. 2017, 7, 44229. [CrossRef] [PubMed]

144. Lucky, S.S.; Soo, K.C.; Zhang, Y. Nanoparticles in photodynamic therapy. Chem. Rev. 2015, 115, 1990-2042. [CrossRef] [PubMed]

145. Fan, W.; Han, H.; Chen, Y.; Zhang, X.; Gao, Y.; Li, S.; Jin, Q.; Ji, J.; Yao, K. Antimicrobial nanomedicine for ocular bacterial and fungal infection. Drug Deliv. Transl. Res. 2021, 11, 1352-1375. [CrossRef] [PubMed] 